\title{
Kvalita voleb do Poslanecké sněmovny Parlamentu ČR ${ }^{1}$
}

\section{Quality of Elections to the Chamber of Deputies of the Parliament of the Czech Republic}

\author{
IVAN JARABINSKÝ
}

\begin{abstract}
This text focuses on the integrity of elections to the lower chamber of the Parliament of the Czech Republic between 1998 and 2013. Its descriptive nature allows the following two main questions to be answered: What are the problems associated with Czech parliamentary elections? Can we identify any trend in the quality of these elections? The analysis employs a framework based on a "policy accountability" model of democracy previously used by Sarah Birch (2011). The analysis is based on various kinds of sources, mainly international observers' reports, laws, secondary analyses, and local news. The overall assessment of the quality of the analyzed elections is quite positive: Between 1998 and 2006 the quality of elections improved, and while it slightly deteriorated in 2010, it quickly returned back to the 2006 levels. The ability to provide equal information and the effective adjudication of disputes are identified as the most problematic aspects. Other parts of the electoral process are well-managed, with only negligible problems on the levels of electoral rules and electoral practice. The overall results differ little from the outcomes of available quantitative studies; however, they offer a deeper insight into the actual realization of demoratic electoral standards.
\end{abstract}

Keywords: Electoral Integrity; Quality of Elections; Czech Republic; Chamber of Deputies; Democratic Elections

\section{1. Úvod}

Otevření volebních soutěží ve střední a východní Evropě na přelomu let 1989 a 1990 značilo trend demokratizace v této oblasti. Nebo alespoň mělo. Od té doby zde zažila demokratizace (Ekiert, Kubik a Vachudova 2007; Bielasiak 2002), stejně jako pravidla volebních soutěží (Šedo 2007), rapidní vývoj různými směry. Volby

\footnotetext{
1 Text byl zpracován v rámci projektu specifického výzkumu Katedry politologie FSS MU „Aktuální problémy politologického výzkumu (kód MUNI/A/1342/2014)“.

2 Interní doktorand, Katedra politologie, Fakulta sociálních studií, Masarykova univerzita, Joštova 10, 60200, Brno, Česká republika/ Department of Political Science, Faculty of Social Studies, Masaryk University, Brno, Czech Republic. Contact: 389860@mail.muni.cz.
} 
jsou samozřejmě integrální součástí demokracie, avšak plní roli její spíše nutné než dostatečné podmínky. Zaměnitelnost těchto dvou pojmů je však stále často relevantním tématem (Huntington 1991; Schumpeter 2004) a velmi užitečným argumentem pro ty, kteř́ obvykle odvozují demokratický status (legitimitu) daného režimu od voleb (viz Geddes 1999; Lust-Okar 2006; Gandhi a Lust-Okar 2009; Magaloni 2008, 2010; Schedler 2002a, 2006). Důležitost kvality samotných voleb, a především pak voleb prvního řádu, se proto jeví jako zásadní, jelikož i ti, kteří ztotožňují demokracii s volbami, trvají na tom, že volby musí splňovat určité standardy.

V rámci současného výzkumu se volby do Poslanecké sněmovny Parlamentu České republiky (PS PČR) umist'ují na předních př́čkách různých, převážně kvantitativně založených, hodnocení. Tyto projekty jako Varieties of Democracy (V-Dem) nebo Electoral Integrity Project (EIP), př́padně Electoral Malpractice Index (Birch 2011) staví na expertních šetřeních nebo na analýze reportů hodnotících samotné volby a obvykle postihují většinu aspektů voleb. Některé výzkumy jsou však prováděny retrospektivně a pravděpodobně tak uniká značné množství informací. $\mathrm{V}$ rámci samotného hodnocení navíc nedochází $\mathrm{k}$ pojmenování konkrétních problémů, ale pouze $\mathrm{k}$ ohodnocení indikátorů. $\mathrm{K}$ prvně jmenovanému je totiž nutná hlubší analýza, které se v celé komplexnosti voleb nedostává.

Cílem tohoto textu je pojmenovat jednotlivé problematické aspekty prvořadých voleb v České republice, tedy voleb do PS PČR, které mohou hrát při zmíněných hodnoceních roli, a sledovat, jak se tyto problémy $\mathrm{v}$ čase proměnujú. Hlubší analýza totiž může přibližit ty problémy, které nejsou ve výše zmíněných hodnoceních specifikovány nebo jsou dokonce opomíjeny, čímž se zvyšuje validita výsledného hodnocení. Př́ijmeme-li Diamondovo (2002: 25) stanovisko, že pro možnosti měření je vhodné odlišit volební demokracii od liberální demokracie, přičemž $\mathrm{k}$ takovémuto měření má docházet odděleně, bude ekvivalentem vysoké volební integrity vysoká úroveň volební demokracie. Časové období pro výzkum je především kvưli dostupnosti relevantních dat omezeno na období od volebního cyklu spjatého s volbami v roce 1998 až do voleb 2013. Text pracuje s dvěma hlavními okruhy výzkumných otázek: Zaprvé, jaké jsou nejvýznamnější problémy voleb v čase; a zadruhé, zda můžeme z hlediska kvality voleb identifikovat nějaké trendy.

Předkládaná studie staví $\mathrm{v}$ prvním plánu na datech ze zpráv volebněpozorovatelských misí OSCE, které jsou doplňovány a rozšiřovány reporty dalších (ne)vládních organizací. Předností těchto zdrojů je jejich aktuálnost v každých volbách a též obecná relevantnost a kvalita (Kelley 2012: 9). Především volebněpozorovatelské zprávy OSCE předkládají velmi systematický a důkladný soubor dat naprríc volbami, ale i v rámci jednotlivých voleb. Tyto reporty (nebo jejich části) se přitom omezují výhradně na volební soutěž, což umožňuje pominout jiné 
aspekty liberální demokracie, které se voleb prrímo netýkají. Tato data jsou následně prohlubována prostřednictvím dalších pramenů, a to př́slušných zákonů spjatých s volbami, nálezů relevantních soudů (zde Ústavního soudu [ÚS] a Nejvyššího správního soudu [NSS]), dalších sekundárních analýz konkrétních aspektů sledovaných voleb a konečně mediálních výstupů, které slouží jako jakýsi watch-dog upozorñující na eventuální problémy. Prohloubení zjištění OSCE na základě dalších zdrojů pak umožňuje tyto zdroje využívat v případech, kde zprávy OSCE absentují, což zajišt'uje kontinuitu sběru dat.

$\mathrm{V}$ teoretické části textu je tedy představen konceptuální rámec pro hodnocení kvality pěti sledovaných volebních cyklů. Následuje empirický rozbor jednotlivých oblastí volební integrity, který poukazuje na odchylky od normativně pojatých demokratických voleb. Před samotným závěrem jsou prezentovány souhrnné výstupy opřené o př̀edchozí zjištění.

\section{Koncept volební integrity}

Ve snaze postihnout celou komplexitu volebního procesu se jeví jako nejvhodnější využití bud' normativně demokratického přístupu, nebo přístupu založeného na mezinárodně uznávaných standardech voleb. Jako do jisté míry přelomovou můžeme označit práci Sarah Birch (2011), která jako jedna z prvních empiricky posuzovala komplexní kvalitu voleb z hlediska jejich nedostatků, a to na pozadí „policy accountability“ modelu demokracie. Ten je charakterizován situací, kdy voliči volí na základě zhodnocení nabízených politik (policy) jak ze strany vlády, tak jejími možnými alternativami. Vláda má přitom monopol na zajištění veřejných statků (policies) (Birch 2011: 13). Tento model je dále definován normativní sadou kritérií (viz dále).

Problém tohoto prístupu spočívá $\mathrm{v}$ pluralitním charakteru normativní demokratické teorie, kdy se interpretace jednotlivých elementů u různých autorů a autorek často liší, a také $\mathrm{v}$ přenositelnosti demokratických hodnot do různých prostř̌edí, v nichž se s nimi občané nemusí ztotožňovat. To má dopad i na prrípadnou komparabilitu. Mandátová teorie, využívaná Birch, dále opomíjí možnosti klientelistických vazeb, jež poskytují výhody podporovatelům té které strany (Norris 2014: 37-38).

Srovnáme-li níže rozvedený koncept Sarah Birch s konceptem vystavěným na základě obsahů obecně přijímaných mezinárodních smluv, je zjevné, že druhé jmenované vychází z prvého. Obrázek 1 ilustruje ty široce sdílené standardy, na nichž staví i výzkum EIP. 
Schéma 1: Přehled široce uznávaných mezinárodních norem
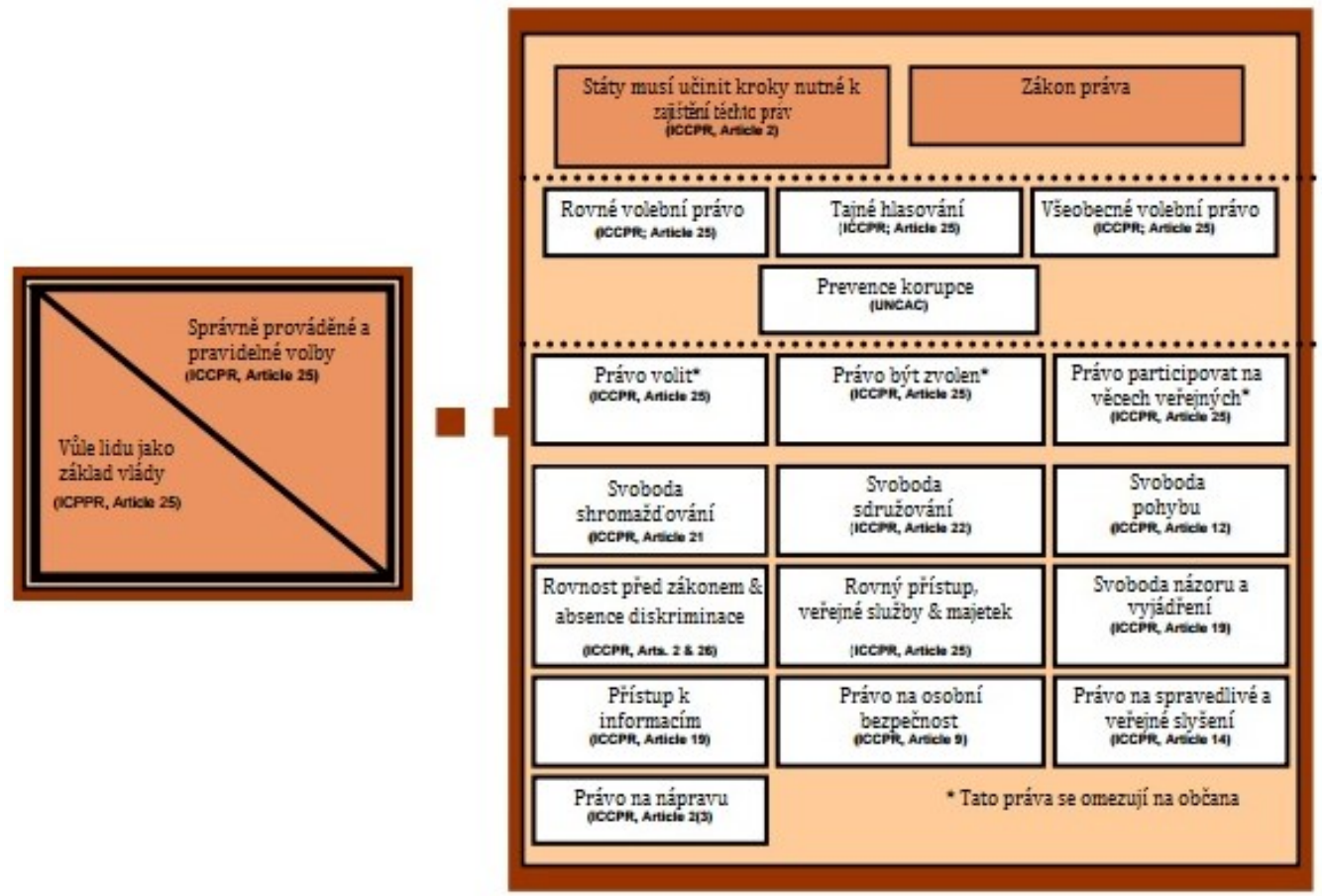

Zdroj: Davis-Roberts a Carroll (2010), překlad autor.

Poznámka: ICCPR = International Covenant on Civil and Political Rights (Mezinárodní pakt o občanských a politických právech)

Představené závazky však svým dopadem sahají i za hranice volební soutěže. K výhradnímu hodnocení kvality voleb je nutné zabývat se danými standardy pouze do té míry, do jaké mohou ovlivňovat volební výsledky. Zaměrujeme-li se tedy výhradně na úroveň volební soutěže, nemusí neúplné naplnění některé z těchto norem znamenat nutně snížení volební integrity.

Při bližším pohledu je žrejmé, že mezinárodní závazky využívané EIP jsou provázány s dodržováním všech principů demokratických voleb podle konceptu Sarah Birch (viz dále). Je však nutné dodat, že ne ve všech ohledech jsou jí stanovené nároky vynutitelné. Týká se to především požadavku rovnosti $\mathrm{v}$ různých fázích cyklu, jako např́klad při poskytování informací, kdy se mezinárodní závazky omezují spíše na princip zajištění svobody názoru a projevu, či prrístupu k informacím, což by měl zajišt'ovat stát.

To znamená, že normativní koncept Birch je formulovaný šíreji než koncept vymezený na základě mezinárodně uznaných principů. Tato studie se snaží zjistit demokratičnost volby bez ohledu na míru internacionalizace demokratických principů a přiklání se $\mathrm{k}$ normativnímu pojetí; při formulaci normativního 
konceptu tedy vycházím z normativních požadavků demokratických voleb, které nastiňuje Birch (2011). Jsou prritom hodnoceny rozpory s jednotlivými principy demokratické soutěže, jmenovitě inkluzivitou, rovností, svobodou a transparentností. Princip transparentnosti je v tomto ohledu poměrně nový a je zde zařazen z důvodu zajištění legitimity procedur. Naplňování jednotlivých požadavků pak bude hodnoceno na dvou úrovních, a to jak z hlediska pravidel volební soutěže, tak na základě toho, jak byly dané standardy naplňovány v praxi.

\section{a. Koncept demokratických voleb podle Sarah Birch}

Přestože práce Sarah Birch (2011) přistupuje k hodnocení kvality voleb negativně, tj. s pomocí negativně vymezených indikátorů, ukazuje se dnes tento př́stup jako méně vhodný $z$ důvodu neustálé adaptace pachatelů podvodů na nové podmínky. Předkládaný text proto vymezuje indikátory pozitivně, $\mathrm{v}$ souladu s původními předpoklady S. Birch. Jako standardy demokratických voleb jsou identifikovány: právo volit, možnost volit, právo být (z)volen, rovné informace, svobodné vyjádření preferencí, přesné sčítání výsledků, neutrální převod hlasů na mandáty a efektivní rozhodování sporů (Birch 2011: 20-26). ${ }^{3}$ Všechny prritom mají stejnou váhu, jelikož následná operacionalizace každého z nich sleduje tuto logiku: Nejlepšího hodnocení dosahují ty reálie, jež jsou plně v souladu s danými volebními standardy, které mají zajišt’ovat demokratickou nepředvídatelnost volebních výsledků, zatímco nejhorší hodnocení připadá na jevy v rozporu s danými kritérii, které volební výsledek přímo předurčují. Střední hodnocení náleží reáliím, které jsou $\mathrm{v}$ rozporu s ideálem, avšak mají potenciál se částečně odrazit ve výsledku.

Právo volit by mělo být všeobecné. Obvykle je definováno schopností člena dané komunity (občana) volit. Tato způsobilost je obvykle omezena věkem (1621 let) a mentálními schopnostmi. Další typy omezení jsou v pojetí policy accountability modelu demokracie nadbytečné (přestože mohou mít jiné výhody).

Mo ̌nost volit jde nad rámec volebního práva a je spjata s prostředím a možností udělit svůj hlas. Voliči musí mít zajištěn př́istup k volebním urnám a dostupné vybavení nutné kudělení hlasu. To znamená vysoké organizační zajištění voleb a vybavení volebních místností. Náročnost udělení hlasu musí odpovídat schopnostem daného elektorátu. Omezení v tomto smyslu je ospravedlnitelné jen $\mathrm{v}$ intencích nutnosti zajištění některých dalších principů jako např́klad tajnosti hlasování.

Právo být (z)volen je zajištěno otevřenou volební soutěží a tedy možností kandidatury. Překážky v tomto smyslu musejí být minimalizovány, přičemž je nutné brát v potaz možné negativní důsledky př́lišné nabídky pro voliče. Měla by být umožněna kandidatura jednotlivců, dalších uskupení a stran. Ideálně by žádný

\footnotetext{
${ }^{3} \mathrm{~K}$ operacionalizaci těchto oblastí na základě následujícího teoretického vymezení viz príloha 1.
} 
z těchto kandidátů neměl být nijak diskriminován. Toho však reálně dosáhnout prakticky nelze a existují tak bud' formální (občanství, věk) nebo registrační (platby, podpora-podpisy, předložení stranických informací, atp.) podmínky pro kandidaturu. Nad rámec zmíněných formálních požadavků jsou další restrikce demokraticky neobhajitelné, nicméně často žádoucí pro fungování režimu jako takového. ${ }^{4}$ Registrační požadavky jsou přijatelné s ohledem na zamezení zbytečných registrací a z toho plynoucích problémů. Takovéto požadavky jsou obhajitelné do té míry, do jaké nevylučují relevantní alternativy.

Rovné informace jakožto princip jdou nad rámec rovnosti jako takové. Tento princip má zajišt'ovat voličům svobodný prístup $\mathrm{k}$ různorodým, adekvátním informacím. Z toho vyplývá nutnost poskytnout svobodu informací a vyjádření. Kandidáti tak musejí mít možnost se prezentovat a tudíž i rozšiřovat potřebné informace, a to za rovných podmínek. Masová média by měla zajišt'ovat objektivní a přesné informování, stejně jako rovné možnosti placené kampaně pro všechny kandidáty. Objektivita informování je nicméně nedostižný ideál, který je možné naplňovat spíše skrze pluralitní mediální prostředí, zajišt’ující možnost vyjádřit se všem relevantním stranám, čímž mohou být př́padné dezinterpretace napravovány. Pro účely této práce tedy z výše zmíněného vyplývá, že je nutné zajistit široké mo ̌nosti prezentace, spravedlivé prerozdèlováni financí (legitimita veřejného financovánî) a transparentnost financování (legitimita soukromého financovánî), kteréžto se týkají prostředků $\mathrm{k}$ vedení kampaně, a dále minimalizovat qaujatost médii (především masových) v praxi i skrze jejich strukturu (k operacionalizaci viz pŕíloha 2).

Možnostmi prezentace se rozumí komparativně dostatečný počet přístupových bodů (to znamená minimální omezení prezentace především na veřejných prostranstvích $\mathrm{v}$ médiích a na internetu) pro vlastní prezentaci. K těmto komunikačním kanálům pak musí být zajištěny rovné možnosti př́stupu a pokrytí všech subjektů. To je vzájemně provázáno, jelikož nepokrytí všech subjektů automaticky značí bud' nerovné možnosti př́stupu (pakliže by strany samy neodmítaly sebeprezentaci), nebo nedostatek prístupových bodů, a naopak.

Otázka spravedlnosti financování stran se $\mathrm{v}$ tomto textu zaměřuje na oba aspekty diskuse kolem financování stran. Umožnění soukromého financování je nutné kvưli právu vyjádřit podporu konkrétním subjektům. Toto by však mělo být ošetřeno maximální transparentností, aby veřejnost mohla kontrolovat, zda volené subjekty skutečně reprezentují vůli voličů a nikoli vůli „investora“. Veřejné financování má pak za úkol především zajistit prostředky i pro menší strany, aby byly konkurenceschopné v předvolební soutěži a nebyly upozaděny jen z finančních důvodů (viz př́loha 3). Funkce přerozdělování veřejných prostředků

\footnotetext{
${ }^{4}$ Práce bude v tomto bodě pracovat s předpokladem snahy o zachování demokratického zřízení. Proto za zvýšení formálních požadavků nad rámec věku a občanství nebudou brány ani restrikce ve věci kandidatury subjektů, jejichž cílem je zrušení demokratického zř́zení.
} 
by měla být spravedlivá, tedy s lineárním, případně logaritmickým průběhem (zajištění pouze dostatečného množství zdrojů), avšak nikoli exponenciálním. Pakliže některé strany dosahují na veřejné př́spěvky, měly by na ně dosahovat všechny subjekty. Každá z těchto možností financování s sebou nese výhody i rizika, přičemž nelze určit obecně platné vhodné nastavení. Komparativně jsou obě možnosti hojně užívány jak separátně, tak v kombinaci (ACE Electoral Knowledge Network 2016). Musí být proto zajištěna takto stanovená dobrá praxe v rámci každé z těchto složek (viz př́lohy 2 a 3), přičemž v praxi se navíc sleduje, nakolik se př́padné nespravedlnosti projevují při výdajích na kampaň.

Práce s informacemi ze strany (především masových) médiî ${ }^{5}$ by měla být nezaujatá. Studie v tomto bodě sleduje především dva aspekty. V rovině pravidel se jedná o nastavení prostředí, v němž média fungují, tedy o možnosti dohledu nad médii a jejich vlastnickou strukturou. V praktické rovině se však nedá očekávat, že média nebudou stranit některým subjektům, což je poměrně obvyklý jev. Mělo by však docházet $\mathrm{k}$ tomu, aby pluralita médií zajišstovala dorovnávání takovéto zaujatosti, tedy aby některá média informovala $\mathrm{v}$ (ne)prospěch konkrétních subjektio, zatímco jiná v (ne)prospěch jejich alternativ (viz prŕloha 2). ${ }^{6}$

Svobodné vyjádření preferencí Birch ztotožňuje s vyjádřením vlastní vůle u volební urny, což by měla zajistit povinná tajnost volby. Rovněž je nutná možnost vyjádřit svůj názor mimo volební urnu, a to v průběhu celého volebního cyklu. To jednak napomáhá při formování samotné preference, ale zároveň to plní funkci udržení samotného kandidáta ve hře. Jestliže by např́klad shromažd'ovací právo bylo omezeno, kandidát by tak mohl být omezen na informovanosti o jeho podpoře a mohl by od voleb odstoupit.

Presné sč́tání výsledkư je nutnou podmínkou pro zjištění opravdové vůle voličů. Musí být proto zajištěno jak nestranné posouzení všech lístků, tak jejich bezchybné započítání, tabelace a reportování.

Neutrálni prevod blasu na mandáty, následující po sečtení hlasů, musí být na základě daných pravidel prováděn nestranně. Birch zde uvádí, že „formální prahy jsou nežádoucí na volební úrovni z demokratického úhlu pohledu (třebaže mohou mít výhody ve smyslu politické odpovědnosti legislativy)“ (2011: 25). Proporční výstupy volebních pravidel jsou sice možná ideální v demokratickém slova smyslu, jelikož relativně přesně reflektují vưli elektorátu, avšak musejí odrážet rovněž potřeby daného zř́izení (polity). Je zjevné, že přitom musí být zamezeno praktikám jako mallaportionment (což se projevuje na rovnosti hlasů) nebo

\footnotetext{
5 Pojmem masová média jsou pro účely této studie myšlena média, která jsou nákladově nebo pokrytím významná $\mathrm{v}$ daných volbách. Tato média se v čase proměňují a práce tak zůstává závislá na sekundárních analýzách, jejichž sledovaný vzorek médií se mění, nicméně vždy jsou v tomto smyslu středem zájmu nejvýznamnější média v zemi.

6 Tento př́stup je nejpoužívanějším typem analýzy obsahu médií spojených s poslaneckými volbami v ČR a jeví se proto jako nejvhodnější zdroj dat pro longitudinální výzkum.
} 
gerrymandering (kdy jsou hranice obvodů upravovány tak, aby zajistily vyšší zisky konkrétním stranám). Responsivita systému (obecně vyšší u většinových systémů) a reprezentativnost (obecně vyšší u proporčních systémů) se vzájemně doplňují a můžeme říci, že různým politickým uspořádáním vyhovuje lépe bud’ jedno, nebo druhé (Birch 2011: 20-26). Co je však možné zajistit v obou typech systémů je rovnost hlasu. Otázka proporcionality je totiž spjata s tím, na jaké úrovni je jí dosaženo (jednomandátové obvody - vícemandátové obvody - celostátní obvod). V praxi je nicméně možné zajistit na úrovni všech těchto typů obvodů takové nastavení pravidel, aby počet hlasů nutný ke zvolení kandidáta $\mathrm{v}$ tom kterém kraji byl přibližně stejný jako $\mathrm{v}$ dalších obvodech. Při hodnocení tohoto ukazatele tedy budeme, kromě hranic volebních obvodů a podílu propadlých hlasů, sledovat schopnosti volebního systému udržet racionálnî úroveň rovnosti hlasů např́ić těmito obvody a celostátně.

Efektivni rozhodováni spori musí být zajištěno ve všech fázích volebního cyklu. Musí být přitom nestranné a v jeho rámci musí být umožněno efektivně posoudit a prípadně napravit problémy spjaté s jakoukoli výše zmíněnou oblastí (Birch 2011: 20).

\section{Kvalita voleb v letech $1998-2013$}

\section{a. Právo volit}

Pravidla: Pro volby v roce 1998 bylo aktivní volební právo omezeno ze zákona věkem 18 let a českým občanstvím. Případnou překážkou mohlo být omezení osobní svobody $\mathrm{z}$ důvodu ochrany zdraví lidu a zbavení způsobilosti k právním úkonům (Zákon č. 247/1995 Sb., ve znění ke dni 21. 6. 1998). To je však v souladu s podmínkami stanovenými Sarah Birch, přičemž jako nadbytečné se může jevit jedině omezení osobní svobody, které je však dále ospravedlněno velmi specifickými podmínkami. Zákon teoreticky rovněž umožňoval nezapočitání výsledků z konkrétního volebního okrsku, pakliže předseda okrskové komise nesplnil své závazky, což mohlo mít stejný důsledek jako zbavení volebního práva voličů $\mathrm{v}$ daném okrsku. Všechna tato pravidla zůstala $\mathrm{v}$ platnosti pro všechny následující volby. V roce 1998 však existoval další problém, který spočíval v náročných pravidlech pro získání občanství pro obyvatele území ČR (a často ve znemožnění jeho získánî), kteří zde dlouhodobě pobývali (Zákon č. 40/1993 Sb., ve znění ke dni 21. 6. 1998). To bylo do následujících voleb vyřešeno úpravou usnadňující zisk státního občanství těmto osobám (\$ 18, \18a zákona č. 40/1993 Sb., ve znění ke dni 16. 6. 2002).

Hodnoceni: 1998 - 2; 2002 - 1; 2006 - 1; 2010 - 1; 2013 - 1.

\footnotetext{
${ }^{7}$ Blíže viz sekce $3 g$ a př́loha 4.
} 
Praxe: V praxi se v dané periodě nesetkáváme s omezeními na základě ochrany zdraví lidu. Jedná se spíše o preventivní opatření a ve velkém měřítku (napríklad epidemie) k takovému omezení nedocházelo. Rovněž se nestávalo, že by nebyly započítávány hlasy z některých okrsků. Zákon o nabývání a pozbývání státního občanství v roce 1998 znevýhodňoval především romské obyvatele, kteří se na území ČR přesunuli po 2. světové válce z území dnešního Slovenska. Podle odhadu se mohlo jednat až o 10 000-25 000 lidí. V praxi navíc docházelo k diskriminačnímu uplatňování tohoto zákona (Romové v České republice 2000). To znamená systematické omezení možnosti hlasovat konkrétní skupině obyvatel (hodnocení 3), což mělo teoretický potenciál ovlivnit výsledek, přestože není zř̀jmé jakým směrem.

Hodnoceni: 1998 - 3; 2002 - 1; 2006 - 1; $2010-1 ; 2013-1$.

Celkové hodnocení: 1998 - 5; 2002 - 2; 2006 - 2; 2010 - 2; 2013 - 2.

\section{b. Možnost volit}

Pravidla: Hlavním problémem voleb 1998 z hlediska uplatnění volebního práva byla nemožnost volit ze zahraničí, což eliminovalo skupinu obyvatel z možnosti podílet se na výsledku voleb. Birch přitom uvádí, že „všichni oprávnění členové komunity by měli být schopni volit, bez ohledu na jejich lokaci“ (2011: 21). Zákon ovšem neumožnil volit dálkově nebo v předstihu. Na území ČR naopak voliči mohli (po celé sledované obdobî) využít volebního průkazu k volbě mimo „svưj““ okrsek. Voličské seznamy sice dále nejsou př́stupné veřejné inspekci, avšak voličům je umožněno zkontrolovat si správnost údajů $\mathrm{v}$ nich obsažených a př́padně mohou požádat o úpravy (Zákon č. 152/1994 Sb., ve znění ke dni 21. 6. 1998). Teoreticky je možné, že nastane překážka k výkonu volebního práva tím, že po uzavření stálého seznamu voličů bude potenciální volič hospitalizován mimo území svého volebního okrsku (Ministerstvo vnitra ČR s.d.). Od roku 1998 došlo pouze ke dvěma změnám. Od voleb v roce 2002 je umožněna volba ze zahraničí, ačkoliv pouze osobně na zastupitelském úřadě (OSCE 2002: 6), což představuje nejdůležitějš́ změnu ve směru inkluze voličů do volebního procesu. Stávající problémy jsou tak spíše logistického charakteru, přičemž vyšší participaci v zahraničí by usnadnila možnost volit distančně. Z hlediska navýšení volební účasti se však jedná o do jisté míry diskutabilní instituty. Voliči v zahraniční tak již nejsou z volby vyloučeni, přesto nepřiměřeně zvýšené (především logistické a finančnî) náklady na volbu ze zahraničí mohou mít obdobné vyústění. Dopad na samotný výsledek je však diskutabilní s ohledem na nepředvídatelnost volební účasti $\mathrm{v}$ zahraničí. Od těchto voleb je rovněž nutné poskytovat informace $\mathrm{v}$ jazycích národnostních menšin v jasně definovaných oblastech, což potenciálně dále zvyšuje schopnost bezproblémově odvolit (OSCE 2002: 15; \ 15 odst. 4 zákona č. 247/1995 Sb., ve znění ke dni 16. 6. 2002).

Hodnoceni: 1998 - 3; 2002 - 2; 2006 - 2; 2010 - 2; 2013 - 2. 
Praxe: Nebyly evidovány žádné problémy s voličskými seznamy a ani s využíváním voličských průkazů. Vysoký podíl platných hlasů rovněž naznačuje bezproblémovost hlasování (1998: 99,58 \%; 2002: 99,56 \%; 2006: 99,64 \%; 2010: 99,37 \%; 2013: 99,26 \%). Ve volbách 1998 však byla možnost volit v praxi de facto limitována pravidly a z voleb byla znovu vyloučena část občanů pobývajících v zahraničí, pakliže se nerozhodli vrátit na území ČR. Volební účast v zahraničí je od roku 2002 velmi nízká a je ovlivněna především nutností hlasovat osobně. To znamená, že teoretická možnost hlasování ze zahraničí v praxi není tak docela naplněna, a je možné, že množství voličů zůstává z procesu volby vyloučeno kvůli jejich momentálnímu místu pobytu. Př́pady pochybení z hlediska umožnění hlasování prakticky neexistují, nebo jsou zcela marginálního rozsahu.

Hodnoceni: 1998 - 3; 2002 - 2; 2006 - 2; 2010 - 2; 2013 - 2.

Celkové hodnocení: 1998 - 6; 2002 - 4; 2006 - 4; 2010 - 4; 2013 - 4.

\section{c. Právo být (z)volen}

Pravidla: Po celé zkoumané období je pasivní volební právo limitováno pouze občanstvím ČR, aktivním volebním právem a věkem 21 let (čl. 19 odst. 1 ústavního zákona č. 1/1993 Sb., ve znění pozdějších předpisů), kteréžto omezení se nijak zvláště nevymykají běžné praxi. Ve volbách v roce 1998 bylo k efektivní kandidatuře ve volbách nutné, aby strana složila volební kauci 200000 Kč za každý obvod, v němž podává kandidátní listinu. Strany, které celostátně překročily $5 \%$, měly nárok na její vrácení. Pro předložení kandidátní listiny ve všech osmi obvodech to tedy znamenalo zaplatit $1600000 \mathrm{Kč}$, přičemž předložení méně kandidátních listin logicky snižovalo šanci na překročení klauzule. Úspěšné strany byly takto zvýhodňovány a pro strany s nejistým úspěchem to mohlo znamenat likvidaci. Jestliže pak strana nezískala ani $3 \%$ hlasů, neměla nárok ani na další příspěvek na úhradu volebních nákladů, který činil 90 Kč za jeden hlas. Výše hranice pro tento príspěvek navíc byla posuzována spíše jako vysoká (viz nález Ústavního soudu ČR ze dne 13. 10. 1999). Přestože je možné využít určitých nástrojů pro koncentraci stranické soutěže a zajištění vážnosti volby, docházelo v těchto volbách ke kumulaci několika prvků, které působily diskriminačně vůči menším stranám, přičemž stanovovaly relativně vysokou hranici pro príjem veřejných peněz.

Ve volbách v roce 2002 (a ve všech následujících) už však byla situace odlišná. Volební kauce se změnila na nevratný príspěvek, což zmírnilo znevýhodnění menších stran oproti větším. Výše tohoto př́spěvku rovněž doznala

\footnotetext{
8 Ve volbách v roce 2010 se mohla na mírném zvýšení podílu neplatných hlasů podepsat i nepravdivá zpráva kolující po internetu (hoax), která nabádala voliče k udělení neplatného hlasu, přičemž avizovala, že tímto způsobem strany nezískají za jimi odevzdaný hlas finanční příspěvek (Šrajbrová 2012).
} 
změn - poklesl na 15000 Kč za kandidátní listinu v obvodě. Pro kandidaturu na celém území (nově 14 obvodů) tak strana musela zaplatit 210.000 Kč, což představuje výrazné snížení. Navíc došlo i ke zmírnění hranice pro zisk příspěvku na úhradu volebních nákladů na hodnotu $1,5 \%$, přičemž strana získala 100 Kč za každý hlas. Tím se rozrostl okruh stran, které měly nárok na tyto finanční prostř̌edky, a rovněž se nepatrně zvýšila suma za získané hlasy, což dosud zajišstuje finance i malým stranám. Možnosti jejich kandidatury jsou však stále mírně omezeny.

Podmínka zaplacení volební kauce se v roce 1998 nevztahovala k samotné kandidatuře, nýbrž k tisku hlasovacích lístků (『 35 odst. 3 zákona č. 247/1995, ve znění ke dni 21. 6. 1998). V př́padě nezaplacení proto nebylo jasné, zda se jedná o kandidující subjekt, kterému „pouze“ nemá být vytištěna kandidátní listina, nebo se o kandidující subjekt nejedná.

Požadavky pro vznik a činnost stran nejsou nijak zvlášt' náročné (č. 424/1991 Sb., ve znění pozdějších předpisů) a jsou zdůvodněny v zákoně: ${ }^{10}$ Strany/koalice mohou kandidovat, pokud jim není pozastavena činnost ( $\mathbb{\$} 31$ odst. 1 zákona č. 247/1995 Sb., ve znění ke dni 21. 6. 1998), od roku 2002 jim pak zákon ukládá povinnost registrace. Tato opatření omezující možnost kandidatury mají dvě funkce. Zaprvé se jedná o sankce za porušení principů, které jsou pro všechny strany a hnutí stejné; tím nutí strany dodržovat stanovená pravidla a zajišt'uje tak tzv. level playing field (narovnává podmínky hry). Zadruhé se jedná o prostř̌edky cílící na zachování demokratického uspořádání. V rozporu s teoretickým vymezením kritéria práva být (z)volen se však jeví problematicky požadavky na zajištění bezpečnosti a mravnosti při činnosti stran (tamtéž). Tím je omezena policy nabídka a tyto požadavky jsou potenciálně dále zneužitelné. Je však nutné upozornit, že snížené hodnocení je dáno především nekompromisností takto vymezeného kritéria, jež se soustředí na maximální otevřenost a rovnost podmínek kandidatury. Pro reálné fungování systému by nicméně odstranění především bezpečnostního požadavku mohlo způsobit značné problémy.

Dále není umožněna individuální kandidatura. Zákon platný pro volby 1998 umožňoval podávat kandidátní listiny pouze registrovaným politickým stranám a koalicím (Zákon č. 247/1995, ve znění ke dni 21. 6. 1998); od voleb 2002 je okruh subjektů dále rozšsiřen o politická hnutí. Na druhou stranu je po celé sledované období umožněna kandidatura kandidátů bez politické prŕíslušnosti. Je však nutné podotknout, že v prostředí volebních systémů poměrného zastoupení, založených na stranických kandidátkách, není individuální kandidatura obvyklá, jelikož by celou volbu komplikovala a navíc by při nevhodně zvolených kritériích

\footnotetext{
9 To s sebou nese další komplikace - viz kapitola 3(d).

${ }^{10} \mathrm{~V}$ zájmu ochrany demokracie a lidských práv.
} 
pro takovouto kandidaturu mohlo dojít k celkové nepřehlednosti. Volební zákon by pak individuální kandidáty pravděpodobně dále znevýhodňoval.

Kumulace opatření koncentrujících volební soutěž v roce 1998 byla v principu značně diskriminační, což později potvrdil Ústavní soud (Nález Ústavního soudu ČR, ze dne 13. 10. 1999), proto můžeme hodnotit nastavení pravidel ohledně možnosti kandidatury v těchto volbách hodnotou 3. V dalších volbách byla tato opatření utlumena na míru zajišt'ující racionální omezení kandidatury na ty subjekty, které to s volbami „myslí vážně“, čímž se úspěšně předešlo problémům spjatým s př́padnou př́lišnou nabídkou. Možnosti registrace a činnosti politických stran a hnutí nicméně snižují hodnocení dané hodnocení.

Hodnocení: 1998 - 3; 2002 - 2; 2006 - 2; 2010 - 2; 2013 - 2.

Praxe: Po volbách v 1998 si některé strany stěžovaly OSCE na platby spojené s kandidaturou (OSCE 1998: 4-5). Obdobné stížnosti směřovaly na relevantní soudy jak dříve, tak i v prípadě pozdějších voleb, a je možné očekávat, že dokud budou obdobné instituty zachovány, budou stížnosti neúspěšných stran podávány do té doby, než to strany unaví. Období po volbách 1998 je však odlišné v tom, že strana Demokratická unie a později i skupina senátorư ${ }^{11}$ byly alespoň částeně úspěšné a Ústavní soud potvrdil diskriminačnost pravidel upravujících finanční nároky a kompenzace za účast ve volbách. Pluralita soutěže sice byla v roce 1998 zachována (voleb se účastnilo 13 stran, z toho $12 \mathrm{v}$ každém obvodu), avšak pět stran se voleb neúčastnilo, z toho čtyři z důvodu neschopnosti zaplatit kauci. V praxi byly nicméně eliminovány spíše marginální strany. Navýšení počtu kandidujících subjektů (28) ve volbách 2002 může značit, že v předchozích volbách mohly možnosti kandidatury aspirující subjekty psychologicky omezovat, nebot' počet kandidujících subjektů nakonec nebyl ani poloviční. Hodnocení voleb v roce 1998 má proto hodnotu 2. Nutno podotknout, že na příspěvek na úhradu volebních nákladů dosahují po celé sledované období i strany, které se nedostanou do PS.

V roce 2002 nastal nezvyklý problém. Kandidátní listiny strany Akce za zrušení Senátu a proti vytunelování důchodových fondů (AZS) byly po rozhodnutí krajských soudů registrovány v některých krajích (3 ze 7) i navzdory nezaplacení volebního př́spěvku (OSCE 2002: 10). Tím byla strana oproti ostatním zvýhodněna, avšak dosáhla pouhých $0,2 \%$ hlasů. Přestože se jednalo o marginální stranu, samotný problém byl ve své podstatě poměrně závažný a pakliže by byl využit jinou stranou, mohlo to mít za následek zneplatnění voleb. $\mathrm{K}$ tomu ale nakonec nedošlo. Hodnocení proto zůstává na hodnotě 2.

11 Stížnost skupiny senátorů mimo jiné na zrušení kauce byla podána v kontextu nové úpravy volebního zákona, avšak v principu se tato kauce významně nelišila od předchozí úpravy. 
V roce 2006 v praxi k problémům s neplacením př́spěvků nedochází. V rámci těchto voleb můžeme pozorovat dvě násilné události, a to napadení Jiř́ho Dolejše (KSČM) a Miroslava Váni (ČSSD) (Třeček, Prokop a Jelínková 2006). Z toho však nelze odvozovat, že by tyto akce byly namíreny proti kolektivně vymezené skupině kandidátů. Ani v jedné situaci nebyli vypátráni viníci a nelze vysledovat jakoukoli spojitost. Velmi pravděpodobně se jedná o individuální, nekoordinované a nejasně cílené akce. Oba kandidáti se nakonec voleb účastnili (hodnocení 1).

V roce 2010 už byla situace o něco vážnější. Objevuje se totiž násilí na předvolebních mítincích ČSSD. ${ }^{12}$ Násilí je spojeno prakticky výhradně s kampaní této strany, přestože se jedná spíše o nekoordinované excesy. Situace se však později, i díky změně předvolební taktiky strany, uklidňuje, a výsledek voleb ani kandidaturu jednotlivců nijak neovlivňuje (hodnocení 2).

Strany, které nezaplatily př́spěvek na volby, nebyly registrovány. $\mathrm{V}$ únoru 2010 dochází k rozpuštění Dělnické strany na základě obhajitelných argumentů spojených mimo jiné s ohrožením demokratického zrrízení (Rozsudek jménem republiky, sp. zn. Pst 1/2009), a proto bez vlivu na snížení hodnocení. Kandidáti této strany se navíc voleb účastní na kandidátní listině Dělnické strany sociální spravedlnosti.

V roce 2013 dochází v některých krajích k vyřazení kandidátek Aktivu nezávislých občanů a Československé strany socialistické za nesplnění předepsaných náležitostí. Rovněž byla vyřazena strana „Volební principy prázdných a blokovaných židlí (mandátů)“, která nebyla registrovanou stranou na Ministerstvu vnitra (MV); registrováno nebylo ani sdružení Čeští lvi (Ministerstvo vnitra ČR 2014: 26). Nelze předpokládat, že by některá z těchto stran mohla ovlivnit výsledek voleb. Dané skutečnosti jsou celkově v souladu s bezproblémovými pravidly, nebo minimálně jejich bezproblémovými aspekty, pročež mohou být hodnoceny stupněm 1 .

Hodnoceni: 1998 - 2; 2002 - 2; 2006 - 1; 2010 - 2; 2013 - 1.

Celkové hodnocení: 1998 - 5; 2002 - 4; 2006 - 3; 2010 - 4; 2013 - 3.

\section{d. Rovné informace}

Pravidla: Pravidla v rámci kampaní můžeme rozdělit do tři skupin - otevřenost kampaní, rovné zacházení a financování. Co se týče otevrenosti a svobody v rámci kampaní, můžeme hlavní těžiště změn $\mathrm{v}$ daném období identifikovat mezi volbami 1998 a 2002. Pozitivně je hodnoceno zkrácení doby, v níž je omezeno

12 Bohuslav Sobotka dostal pěstí na mítinku v Brně (Třeček, Lukšová a Prak 2010); dále jde o hozenou sklenici s utopenci k pódiu na mítinku ČSSD v Kladně (Válková a Eichler 2010); žhářský útok na volební stánek ČSSD v Plzni (Blažek et al. 2010); či varování, že manželce Jiř́iho Paroubka hrozí fyzické napadení (Týden.cz 2010). 
zveřejňování předvolebních průzkumů, ze sedmi na tři dny před volbami, přičemž nová úprava počítala se sankcí za její porušení ( $(16$ odst. 5 a 7 zákona č. 247/1995 Sb., ve znění ke dni 16. 6. 2002). Mezi těmito volbami byl také zrušen zákaz agitace 48 hodin před volbami. Od voleb 2002 je nově zaveden zákaz kampaní ve volebních místnostech a v jejich okolí ve dnech voleb, přčemž se jedná pouze o marginální omezení, které umožňuje voličům vyjádřit upřímný hlas bez dalšího ovlivňování.

Hlavním kladem všech sledovaných voleb je zákonem zajištěný minimální prostor pro všechny kandidující subjekty (\$ 16 odst. 3 zákona č. 247/1995 Sb., ve znění ke dni 21. 6. 1998). Znění zákona ovšem zajistilo jeho úplnou vymahatelnost až ve volbách 2002, kdy došlo k ujasnění pojmu kandidující subjekt ( 31 odst. 4 zákona č. 247/1995, ve znění ke dni 16. 6. 2002) a ozřejmilo se tak, komu má být věnovaný čas na kampaň v České televizi (ČT) a Českém rozhlasu (ČRo).

Negativně lze v tomto období hodnotit zrušení zákazu používání místního rozhlasu k volební agitaci, což zvyšuje nerovnost $\mathrm{v}$ př́ístupu $\mathrm{k}$ tomuto zařízení. Svoboda však byla $v$ tomto smyslu více omezena nemožností zvláštní propagace v soukromých rozhlasových a televizních médiích (pod pokutou), ${ }^{13}$ což se od roku 2002 přeneslo i na veřejná média tohoto typu (Zákon č. 231/2001 Sb., ve znění pozdějš́ích předpisů). Po celé sledované období však zůstává zachována možnost pokrytí konkrétních témat $\mathrm{v}$ televizi a rádiích skrze jejich prezentaci $\mathrm{v}$ jiných pořadech či zprávách. Tištěná média zůstávají $\mathrm{v}$ tomto ohledu po celou dobu bez omezení. Před volbami v roce 2013 byla přijata změna, která v zákoně nahrazuje pojem „reklama“ termínem „obchodní sděleni" (viz \2 odst. 2 písm. a zákona č. 231/2001 Sb., ve znění ke dni 1. 6. 2010), kteréžto teoreticky může umožnit čistě politickou reklamu. Rada pro rozhlasové a televizní vysílání (RRTV) však dovozuje, že ,zákon za obchodní sdělení považuje nejspíše i takové sdělení, které podporuje nejenom obchodní prvek soutěže, ale i aktéra či prvek jiných soutěží založených na vzájemně si konkurujících konceptech" (Rada pro rozhlasové a televizní vysílání 2014).

Pro volby 1998 tedy existují omezení množství přístupových bodů k placené reklamě v některých elektronických médiích a zákaz kampaně dva dny před volbami, avšak stranám je umožněno objevit se v médiích nebo v ulicích i jiným způsobem, a proto jsou tato omezení nahlížena jako mírná. Pro další volby jsou pak omezení v některých elektronických médiích rozšířena, nicméně zákaz agitace těsně před volbami je zrušen. Ani v jedněch volbách se však tato omezení neprojevují na schopnosti zajistit minimálně relevantní pokrytí všem stranám a jedná se proto o mírné omezení možností propagace.

${ }^{13}$ To se však mohlo jevit i jako žádoucí, jelikož nebyla bohatším stranám poskytnuta výhoda (další prostor) oproti těm chudším (OSCE 1998: 12). 
Dohled nad médii se po celé období prakticky nemění a je neustále vystavován kritice, jelikož složení hlavních kontrolních orgánů (Rada České republiky pro rozhlasové a televizní vysílání a Rada ČT) odvisí od zainteresovaných subjektů, tedy stran v Poslanecké sněmovně (Zákon č. 103/1992 Sb., ve znění pozdějších předpisů a předpis č. 231/2001 Sb., ve znění pozdějších předpisů; \ 4 zákona 483/1991 Sb., ve znění pozdějších předpisů).

Strany jsou financovány jak z veřejných zdrojů (př́íspěvek na běžnou činnost; na mandát poslance; na úhradu volebních nákladů), tak ze soukromých. V roce 1998 bylo stranám umožněno získat stálý př́spěvek na činnost, jestliže dosáhnou $3 \%$ hlasů. Hodnota tohoto př́spěvku se však od roku 2001 zdvojnásobila, což teoreticky zajišt'uje životnost i neparlamentním stranám. Stejným zákonem byla zdvojnásobena i hodnota př́spěvku na mandát (500.000 Kč ve volbách 1998), což Ústavní soud sice označil za nepř́ípustné, avšak př́spěvek nakonec stejně vzrostl 1,8krát. Pro volby 2013 pak byla hodnota tohoto příspěvku nepatrně snížena o pět procent. Důsledkem těchto změn bylo zvýšení přerozdělovací funkce, tedy větší závislost stran na veřejných prostředcích. Funkce pro rozdělování financí stranám v rozmezí 3-5 \% a nad 5\% jsou však obdobné. Přestože dochází ke zvýšení inkluzivity pro pobírání státních peněž, jsou strany v rozmezí 1,5-3 \% výrazně znevýhodněny oproti úspěšnějším stranám, a to jak pravidly distribuce financí, tak neúměrným finančním skokovým zvýhodněním stran dosahujících $3 \%$ hlasů. Jako možný problém se v kontextu financování jeví př́spěvek na mandát, respektive jeho svázanost sproporcionalitou volebního výsledku. Disproporcionalita totiž automaticky $\mathrm{z}(\mathrm{ne})$ výhodní strany $\mathrm{i} v$ oblasti financí. Úpravy pro sledované volby nabízí v obecné rovině relativně slušné hodnoty proporcionality, přestože ta $\mathrm{v}$ praxi zajištěna není (viz dále). To je od roku 2000 dále umocněno rozšířením př́spěvku na mandát za senátory a krajské zastupitele. Outlý (s.d.) toto opatření zpochybňuje s odkazem na odlišný př́stup ke stranám s mandátem ve sněmovně od stran úspěšných na jiných úrovních. Zavedené strany si tak mohou přijít na velmi vysoké výnosy z těchto voleb, což nerovnost mezi stranami prohlubuje. Princip financování za poslanecké volby se od předchozích voleb tedy nějak zvlášt' nemění, nicméně př́spěvky za další volby, zvýhodňující velké strany, prohlubují finanční nerovnost mezi stranami a jsou využitelné do dalších voleb. Prohlubování závislosti stran na státním financování je nicméně neméně důležité politické téma a mělo by být výsledkem zodpovědné deliberace, spíše než dosavadní nezdůvodněné praxe.

Nakládání s finančními prostředky lze rovněž hodnotit negativně. Je totiž netransparentní, jelikož jedinou povinností stran je jednou ročně předložit Poslanecké sněmovně vágní výroční finanční zprávu (『 18 odst. 1 zákona č. 424/1991 Sb., ve znění ke dni 21. 6. 1998), kterou nelze nijak seriózně kontrolovat. Změnu nepřinesla ani nutnost reportovat výdaje na kampaň (od roku 2001), jelikož není jasné, za které volby ani za co konkrétně jsou finance utráceny. Kontrolním orgánem jsou pritom samy kontrolované strany, které tak nemají 
důvod reportovat pravdivé údaje (Outlý s.d.). Financování samotných kandidátů navíc nepodléhá žádným pravidlům (GRECO 2011: 20-21), přestože motivace ve formě preferenčního hlasování zde existuje. Celý systém financování tak může být snadno obcházen.

Výše naznačené změny pravidel $\mathrm{v}$ jednotlivých oblastech jsou pouze parciální. K jedinému významnému zhoršení dochází v oblasti spravedlnosti financování stran před volbami 2002, kdy nové příspěvky za vybrané druhořadé volby prohlubují skokové navýšení rozpočtu úspěšných stran oproti těm neúspěšným.

Hodnoceni: 1998 - 3; 2002 - 3; 2006 - 3; 2010 - 3; 2013 - 3.

Praxe: V roce 1998 nebylo kvůli nejasnosti s kandidaturou zřejmé, komu mají ČT a ČRo poskytnout bezplatný prostor. Každá instituce se proto rozhodla jinak. Sdružení důchodců, které nezaplatilo volební kauci, poskytlo svůj vysílací čas v ČRo Republikánské straně (SPR-RSČ). Propojenost těchto dvou stran tak umožnila obejít smysl daného nařízení k poskytnutí rovného rozdělení bezplatného času ve veřejném médiu. $V$ dalších médiích byl prostor věnován především parlamentním stranám. Ostatní zde téměř nebyly zmiňovány nad rámec jimi placené reklamy (s výjimkou stran Důchodci za životní jistoty a Demokratická unie) (OSCE 1998: 19-20).

V těchto volbách dále došlo k tzv. „gentlemanské dohodě“, kdy strany dobrovolně zastropovaly výdaje ve vymezeném období kampaně (na 30 milionů Kč) a dohodly se nepoužívat billboardy (tamtéž: 9). Této dohody se však neúčastnila SPR-RSČ, která tím získala oproti ostatním stranám výhodu a vlastně i monopol na billboardy. V praxi však některé strany dohodu nedodržovaly, resp. se objevovaly billboardy ve prospěch ODS nebo v neprospěch ČSSD, což způsobilo znevýhodnění stran loajálních této úmluvě.

Strany se do významných médií dostávaly i přes některá omezení. Selektivní výběr ze strany soukromých elektronických médií se projevil v menším pokrytí malých stran, což je však důsledkem reálného fungování médií. Možnosti placené předvolební reklamy pouze $\mathrm{v}$ některých typech soukromých médií pak omezily možnosti tyto disproporce dorovnávat (přestože se taková aktivita nedala předpokládat). Omezení tedy existovaly jak v některých soukromých médiích (zákaz), tak na veřejných prostranstvích či spíše jejich výseku (gentlemanská dohoda), nicméně obcházen byl i zákon o zajištění rovné prezentace v ČRo (přestože v malé míře). Omezení byla ve všech př́ípadech pouze výrazně dílčí a nespravedlnost při prístupu do éteru je v celkovém kontextu marginální.

Co se týče možné zaujatosti médií, některé kauzy zpochybňovaly profesionalitu žurnalistů. Politici si měli podle některých názorů diktovat témata diskusí i své oponenty (Radiožurnál 1998). Na to rovněž vrhl špatné světlo i případ Ivana Kytky a jeho odvolání z vedení zpravodajství ČT, což někteří 
spojovali s možnými politickými tlaky v reakci na pokusy o změnu fungování zpravodajství.

Z hlediska pozitivních/neutrálních/negativních zmínek o jednotlivých stranách nicméně ČT poskytla velmi vybalancované pokrytí jak kvantitativně, tak kvalitativně (OSCE 1998: 13, 19, 20). Pluralita médií zajistila rozložení z(ne)výhodňování mezi strany a významná periodika, takže se možné disproporce svým způsobem dorovnávaly. To však neplatilo pro některé strany, především SPR-RSČ a Důchodce za životní jistoty, které byly výrazně častěji zmiňovány $\mathrm{v}$ negativním kontextu.

Ve volbách 2002 se ukázalo, že malé strany většinou neměly dostatek financí na vedení smysluplné kampaně, a většina $z$ nich se omezila pouze na zákonem alokovaný prostor ve veřejných médiích (OSCE 2002: 7-8) ${ }^{14}$ Př́ístup těchto stran do vysílání byl velmi omezen. Jedna z mála možností sebeprezentace ve veřejné televizi byla kritizována malými stranami, které zde byly zastoupeny nepravidelně. Obdobný postoj zastávaly i $\mathrm{k}$ poskytnutí většiny prostoru v elektronických i tištěných médiích čtyřem hlavním uskupením (OSCE 2002: 14-15). ČT a ČRo alokovaly volný prostor všem stranám. Obdobné bylo pokrytí v tištěných médiích, kde strany využívaly placené reklamy, přičemž aktivní byly i v propagaci na veřejných prostranstvích a na internetu (OSCE 2002: 8). Znovu pak docházelo k alokaci (malé) části vysílacího času strany Romská občanská iniciativa Národně demokratické straně (OSCE 2002: 8).

Pracovníci různých redakcí byli veřejností i politiky vnímáni jako zaujatí ve prospěch konkrétních stran (čemuž zřejmě nijak nepomohla televizní krize z přelomu 2000/2001). Znovu však byla zajištěna pluralita médií (U.S. Department of State 2003: Section 2) a většina stran byla obecně prezentována v obdobném, neutrálním až negativním, duchu (OSCE 2002: 14).

Zaznamenán byl případ, kdy asi 900 občanů obdrželo obálku pouze s jedním volebním lístkem (ČSSD) (Černý a Veselý 2002). Tím bylo omezeno právo na rovné informace spíše než nemožnost hlasovat jinak, jelikož lístky mohli voliči znovu obdržet ve volební místnosti. Rychlá reakce př́slušných autorit však zajistila doručení nových obálek ještě před volbami.

$\mathrm{V}$ praxi tedy byly menší strany zákonem znevýhodňovány $\mathrm{v}$ príistupu $\mathrm{k}$ veřejným penězům, což se projevilo i v nákladech na kampaň. Mediální prostor většinou okupovaly čtyři hlavní kandidující subjekty a vláda, nicméně malé strany měly prostor $\mathrm{v}$ médiích zajištěn, přestože velmi omezeně. Pluralita zdrojů informací byla zachována, čímž byl do jisté míry narovnán obsah zpráv jednotlivých redakcí, jež byly obecně vnímány jako zaujaté.

Ve volbách 2006 byly nejen televizní duely charakteristické především osobami lídrů hlavních dvou stran (Matušková 2006: 63; Petrová 2006: 48), což

${ }^{14}$ Je nicméně nutné vzít v potaz, že ve volbách 2002 kandidovalo až 28 subjektů. 
bylo jedním $\mathrm{z}$ důvodů potlačení prostoru pro menší uskupení, která se prezentovala převážně $\mathrm{v}$ tisku. Př́stup do médií byl nicméně zajištěn všem stranám, a to v ČT a ČRo (Usnesení NSS, č.j. Vol 15/2006).

Znovu došlo $\mathrm{k}$ předání volného času ve vysílání veřejnoprávního média, a to od Strany české pravice ve prospěch ODS. V zanedbatelné míre se objevuje i chyba v podobě distribuce pouze tř́ lístků (ODS) samostatně uložených v distribuované obálce, což bylo neprodleně napraveno (ČTK 2006).

Deníky znovu nadržovaly některým stranám, což bylo ovšem opět vyrovnáváno pluralitou zdrojů (Petrová 2006: 52, 60). Není totiž bez zajímavosti, že po úniku Kubiceho zprávy (viz dále) se např́klad deník Právo vyjadřuje o ČSSD takřka výhradně pozitivně (viz Petrová 2006: 55).

Hlavní událostí těchto voleb se stal únik utajovaných a neověřených informací z tzv. Kubiceho zprávy do médií, z nichž některá přijala tyto informace velmi nekriticky (tamtéž: 51-52; Žantovský 2015: 83-84). Tato skutečnost mohla vést k ovlivnění výsledku ČSSD s ohledem na předvolební atmosféru a samotné načasování úniku. ${ }^{15}$ Medializace ČSSD proto byla výrazně vyšší než u ostatních stran (Sedláček a Herot 2011: 4-5; Petrová 2006: 54). NSS argumentoval, že kvalita voleb touto aférou neutrpěla, protože se $\mathrm{k}$ tématu mohly všechny strany dostatečně vyjádřit (Usnesení NSS, č.j. Vol 5/2006). Tento právnický výklad však není kompatibilní s normativně demokratickým pojetím volební integrity a je navíc omezen vágností zákonné formulace o čestných a poctivých volbách. $\mathrm{S}$ ohledem na vysokou míru pravděpodobnosti ovlivnění výsledku informacemi, které nebyly průkazné, nicméně byly kryty policií, což zvyšovalo jejich relevanci, má zaujatost médií hodnotu 3.

V těchto volbách nastal problém s př́sunem financí některým stranám (SNK-ED, US-DEU), kterým Ministerstvo financí odmítalo vyplatit příspěvky za předchozí komunální (Praha) a krajské volby (Škraňková a Kopecký 2006; Novinky.cz 2006). Strany si tak stěžovaly na nemožnost vést plnohodnotnou kampaň. To dále zvyšovalo nerovnost $\mathrm{v}$ př́sunu financí, což vedlo $\mathrm{k}$ dalšímu prohloubení rozdílu mezi stranami na pomezí volitelnosti a úspěšnými stranami. Obdobně byla znevýhodněna i podreprezentovaná Strana zelených. Míra jejího znevýhodnění se však ve svém důsledku nevymykala nastavenému trendu znevýhodňování menších stran a výrazně neprohloubila znevýhodnění SZ dané dalšími př́íspěvky, pročež hodnocení zůstává na hodnotě 3 .

Volby 2010 představují jistý přelom v počtu nově úspěšných subjektů. Těm se před volbami dostalo ve většině hlavních elektronických médii určitého prostoru, avšak spíše na úkor zavedených malých stran (Sedláček a Herot 2011: 6). Formát 14 předvolebních debat $\mathrm{v}$ ČT a rozhlasu v každém kraji zvětšoval šanci menších stran zviditelnit se. Někdy však nemusely být dosud úspěšné strany

15 Přestože je Kubiceho zpráva obvykle prezentována jakožto negativně ovlivňující výsledek ČSSD, z marketingového hlediska se lze domnívat, že straně mohla i pomoci (Mlejnek 2010). 
přizvány do studia, přestože jejich celostátní podpora byla vyšší než u jiných subjektů. Bylo zajištěno minimální pokrytí všech kandidujících subjektů, které se dostaly i do některých dalších pořadů (Usnesení NSS, č.j. Vol 13/2010).

V hlavních elektronických médiích tak zůstala skutečností velká převaha dvou nejsilnějších stran (Sedláček a Herot 2011: 4). Menší strany byly opět jen marginálně zastoupeny $\mathrm{v}$ soukromých TV (tamtéž: 6), nicméně $\mathrm{v}$ jiných typech médií se objevovaly, což v konečném důsledku mohlo stát za jejich úspěchem (viz Petrová 2010: 121).

Hodnocení obsahové zaujatosti médií je kvůli nedostatku analýz tištěných médií omezeno pouze na elektronická média a na pluralitu tisku, která zůstala zachována (OSCE 2010: 7). Nic jako Kubiceho zpráva se již neopakovalo, což hodnocení o stupeň zlepšuje.

Velmi slabé zajištění financování kampaní se nijak nezměnilo, přičemž odhady výdajů na kampaně jednotlivých stran se velmi lišily. Existují určitá data o financování kampaní, jsou ovšem agregovaná, velmi vágní a blíže nepodložená (pro data viz Matušková 2010). Kontrola financování kampaní tak zưstala minimální. Problémy kolem vyplácení financí stranám v praxi byly oproti předchozím volbám vyřešeny, avšak extrémně dlouhá kampaň mohla být př́ćinou nedostatku finančních prostředků malých stran v jejím závěru (Werner a Verner 2010). ${ }^{16}$

Ve volbách 2013 ČT a ČRo znovu zajistily minimální rovné pokrytí všech subjektů. Nad rámec toho se na obrazovku ČT dostala i některá neparlamentní uskupení, a to při obdobných pravidlech pro výběr zástupců stran do jednotlivých debat jako v předchozích volbách - což znovu kritizovaly malé mimoparlamentní strany, které to znevýhodňovalo (Macková a Hrbková 2014: 86-88). Politici se $\mathrm{v}$ duelech střetávali i na TV Nova, kam se z neparlamentních stran dokázaly prosadit jen ANO a SPOZ. Andreji Babišovi byl navíc poskytnut prostor na přibližně deseti televizních programech (Rada pro rozhlasové a televizní vysílání 2013) k propagaci jeho komerčních aktivit, čímž de facto obešel zákaz politické kampaně v elektronických médiích, jelikož ve druhém plánu této reklamy mohla být skryta politická prezentace.

Prostor věnovaný jednotlivým stranám v hlavních psaných zpravodajských médiích byl až nezvykle vyrovnaný (Macková a Hrbková 2014: 80). Připočteme-li $\mathrm{k}$ tomu zmínky o lídrech daných stran, vidíme víceméně vyrovnání medializace ANO a jejího lídra s nejsilnější ČSSD. Nutno dodat, že vyznění těchto článků bylo právě pro ANO relativně neutrální, na rozdíl od např́klad SPOZ, ODS, které jimi byly spíše znevýhodněny (tamtéž: 82 ).

Pluralita médií byla $\mathrm{v}$ těchto volbách zachována, přestože do jisté míry v okleštěné podobě. Andrej Babiš (předseda ANO 2011) se stal před volbami

\footnotetext{
16 Volby plánované na říjen 2009 nakonec proběhly až v květnu 2010, přičemž ve hře byly mezitím i další termíny.
} 
vlastníkem mediální skupiny MAFRA a s ní spojených vlivných deníků, ${ }^{17}$ což mělo potenciál se projevit $\mathrm{v}$ (ne)závislosti těchto médií. V médiích skupiny MAFRA však nijak výrazný trend zvýhodňování strany ANO oproti jiným médiím pozorovat nelze (Macková a Hrbková 2014: 83). Na druhou stranu však nelze ani nijak průkazně sledovat možnost cíleného opomíjení problémových aspektů podnikání vlastníka mediální skupiny. Některé kauzy nicméně $\mathrm{k}$ podjatosti vybízely, jako např́klad Babišův telefonát redaktorovi Lidových novin (Lidovky.cz 2013a) nebo odchody některých členů redakcí těchto titulů. Kvưli odvolání některých pracovnic byla zpochybněna i nezávislost ČT, což někteří spojovali, $\mathrm{i}$ když neprokazatelně, s politickými tlaky (viz Lidovky.cz 2013b; Jiřička 2013; Bazalová 2013). Zaujatost médií se tak př́liš nelišila od praxe $\mathrm{v}$ předchozích volbách a jejich pluralita byla stále schopná dorovnávat vzniklé disproporce. ${ }^{18}$

Avizované výdaje na kampaň byly výrazně vyrovnanější (Gregor a Macková 2014: 58-59) a již nedocházelo $\mathrm{k}$ neúměrně vyšším volebním výdajům velkých stran, což mohla zapříčinit především předčasnost voleb. Některé strany si v těchto volbách začaly zřizovat transparentní účty pro financování kampaní, což je jistě pozitivní krok, nicméně množství důležitých informací (přestože u každé strany v jiné míre) zůstává stále veřejnosti nedostupných, především pak struktura výdajů (viz Transparentní volby 2013). Otázkou do budoucna nicméně je, jak se bude vyvíjet vyrovnanost volební soutěže ve vztahu k ANO 2011, které mělo z neparlamentní pozice nejen nejdražší kampaň (Gregor a Macková 2014: 58-59), ale také její zastoupení v médiích bylo srovnatelné s ČSSD, nepočítaje $\mathrm{v}$ to její outdoorovou kampaň, která běžela od léta 2013 (tamtéž: 61). Z hlediska financí utracených ve volební kampani můžeme stanovit hodnocení jako relativně vyrovnané, jelikož veřejné financování stran se de facto promítlo do výdajů na kampaň jen mírně a některé neparlamentní strany v tomto ohledu mohly konkurovat těm parlamentním. Teoreticky zde však vyvstává další otázka, a tou je udržitelnost argumentace soudů s ohledem na princip odstupňované rovnosti v takovéto situaci. Celkové hodnocení rovnosti informací v roce 2013 tak sice zůstává na hodnotě 3 , nicméně pohybuje se již na samé hranici pro udělení 2 .

Hodnoceni: 1998 - 3; 2002 - 3; 2006 - 3; 2010 - 3; 2013 - 3.

Celkové hodnocení: 1998 - 6; 2002 - 6; 2006 - 6; 2010 - 6; 2013 - 6.

\footnotetext{
${ }^{17}$ MF Dnes, Lidové noviny, Metro a weby iDnes.cz a Lidovky.cz

18 Náklady médií společnosti MAFRA pokrývají jen zlomek mediálního prostředí, přestože se jedná o velmi významná zpravodajská periodika. Z pomezí plošně vydávaných denních periodik však pokrývají zhruba necelou čtvrtinu prodaného nákladu (data pro záŕí 2013 viz ABC ČR (2016)). Do toho však není započítán náklad periodika METRO, ale rovněž ani další tituly jiné periodicity, které však již pod vydavatelství MAFRA nespadají.
} 


\section{e. Svobodné vyjádření preferencí}

Pravidla: Po celé sledované období volič volí za plentou, což má zajistit tajnost volby a možnost svobodného vyjádření (Zákon č. 247/1995 Sb., ve znění pozdějších př̀edpisů). Marek Antoš (2008: 74-79) však upozorňuje na možný nátlak na voliče nebo odtajnění volby na základě označení hlasovacího lístku ještě než volič vstoupí za plentu, jelikož voličovo chování v místnosti může být pod dohledem. Tento fakt snižuje hodnocení tajnosti volby o jeden stupeň. Listina základních práv a svobod (čl. 19 odst. 1) rovněž zajišstuje právo na (nahlášené) shromažd’ování, které ale není podmíněné povolením. Mưže být pouze zamítnuto v odůvodněných př́padech (zajištění práv a bezpečnosti, právního státu, logistiky, nebo kolize s jiným shromážděním; viz \} 1 0 \text { zákona č. 84/1990 Sb., ve znění } pozdějších předpisů). Zákon ve sledovaném období zakazoval pouze činnost politických stran ve školách (『 2 odst. 4 zákona č. 172/1990 Sb., ve znění účinném k 1. 7. 1990; Zákon č. 29/1984 Sb., ve znění ke dni 27. 7. 1995; \ 2 odst. 10 zákona č. 111/1998 Sb., ve znění pozdějších předpisů; \32 zákona č. 561/2004 Sb., ve znění pozdějších předpisư).

Hodnoceni: 1998 - 2; 2002 - 2; 2006 - 2; 2010 - 2; 2013 - 2.

Praxe: V praxi občané volí bez vměšování vládních stran. Shromažd’ovací právo je dodržováno, přičemž spontánní a poklidné demonstrace nejsou nijak omezovány (U.S. Department of State 1999, 2003, 2007, 2011, s.d.). Výjimku tvoří akce odporující výše zmíněným zákonným omezením, čehož však státní orgány nezneužívaly.

V roce 2002 se objevilo nařčení ze strany KSČM na adresu ČSSD z možného nakupování hlasů v mosteckém Chanově, což však zůstalo pouze u daného prohlášení, jež se nijak blíže nevyšetřovalo ani neprokázalo (Černý a Veselý 2002). $\mathrm{V}$ čase rostlo využívání internetu, kde dochází k další interakci mezi voliči a stranami. ${ }^{19}$ Svoboda na internetu je přitom zajištěna. Rozvoj tohoto média však není důvodem ke snižování hodnocení drúvějších voleb, kdy byl prrístup $\mathrm{k}$ internetu omezenějš́í.

Hodnoceni: 1998 - 1; 2002 - 1; 2006 - 1; 2010 - 1; 2013 - 1.

Celkové hodnoceni: 1998 - 3; 2002 - 3; 2006 - 3; 2010 - 3; 2013 - 3.

\section{f. Přesné sčítání výsledků}

Pravidla: Pravidla pro sčítání hlasů byla pro rok 1998 nastavena vhodně. Postup byl jasný stejně jako protokoly, do nichž byly výsledky zapisovány. Každá strana registrovaná v daném kraji měla právo delegovat své zástupce do volebních komisí na všech úrovních, což jim umožňovalo vzájemnou kontrolu (\ 12; 13; 28;

${ }^{19}$ Viz např́klad kampaň TOP 09, SZ (Matušková 2010: 108, 113, 114). 
29 zákona č. 247/1995 Sb., ve znění ke dni 21. 6. 1998). Od voleb 2002 došlo k redukci úrovní, na nichž probíhá sčíání výsledků, a navíc byl celý proces agregace výrazněji převeden do rukou Českého statistického úřadu (ČSÚ), jelikož ke vzájemné kontrole stran dochází již pouze na okrskové úrovni ( $\int 14$ písm. e odst. 3 zákona č. 247/1995 Sb., ve znění ke dni 16. 6. 2002). Ústřední volební komise tvořená zástupci politických stran byla po volbách 1998 nahrazena Státní volební komisí, jejíž členy jmenuje vláda; model volebního tělesa se tak od smíšeného typu přibližil spíše typu vládnímu. V teoretické rovině se předpokládá, že nezávislost tělesa je jakýmsi předstupněm jeho nestrannosti, přestože výzkumy ukazují, že tomu tak v praxi být nemusí (viz Jarabinský 2015).

Díky spíše slabším ochranným prvkům bylo teoreticky možné padělat voličský průkaz, jelikož systém není centralizovaný (Britské listy 2013). To může být zneužitelné $\mathrm{k}$ vícenásobnému hlasování, nicméně až do voleb 2013 nebyla tato otázka nastolena. Logika fungování volby na voličský průkaz má být jištěna proti zneužití odevzdáním průkazu komisi při samotné volbě.

Hodnoceni: 1998 - 1; 2002 - 1; 2006 - 1;2010 - 1; 2013 - 1.

Praxe: Sčitání výsledků bylo ve všech sledovaných volbách v souladu se zákonem a pravděpodobně nevyvstaly $\mathrm{v}$ této věci žádné problémy. V poslaneckých volbách rovněž nebyly žádné náznaky toho, že by voličské průkazy byly zneužíány. Výsledky jsou podrobně publikovány na webu ČSÚ (Volby.cz 2015) a je tak možné je podrobit veřejné kontrole, k čemuž také dochází. Z pomezí všech sledovaných voleb existuje pouze několik př́padů stížností většinou na špatně započtené preferenční hlasy (patrně kvưli lidské chybě), bez potenciálního dopadu na výsledek (Usnesení NSS, č.j. Vol 27/2006, Vol 8/2006, Vol 13/2010, Vol 143/2013-27).

Před volbami 2013 byl vznesen problém možného zneužití voličských průkazů $\mathrm{v}$ návaznosti na jeho tematizaci $\mathrm{v}$ prezidentských volbách téhož roku (Ovčáček a Rovenský 2013). Ministerstvo vnitra proto zareagovalo snahou o vytvoření nových ochranných prvků na voličských průkazech (Vyhláška č. 452/2013 Sb., ve znění ke dni 1. 1. 2014). Předčasný termín voleb však neumožnil těmto opatřením vejít $\mathrm{v}$ účinnost. Přesto se obava z kopírování voličských průkazů ani v těchto volbách neukázala jako opodstatněná.

Hodnoceni: 1998 - 1; 2002 - 1; 2006 - 1; $2010-1 ; 2013-1$.

Celkové hodnocení: 1998 - 2; 2002 - 2; 2006 - 2; 2010 - 2; 2013 - 2.

\section{g. Neutrální př́evod hlasů na mandáty}

Pravidla: Ve volbách v roce 1998 zamezovala v rovném př́stupu k mandátům $5 \%$ celostátní uzavírací klauzule; takováto klauzule není ve světě nijak neobvyklá. Této překážce mohly strany předejít formováním koalic, ovšem i pro ty platila klauzule 
v hodnotě 7,9 a $11 \%$ pro dvou-, trrí-, resp. vícečlenné koalice. Rovnost hlasu např́č volebními obvody byla zajištěna určením velikosti obvodů na základě republikového mandátového čísla. Mandáty se rozdělovaly ve dvou skrutiniích, přičemž v prvním byly rozděleny v osmi volebních obvodech pomocí HagenbachBischoffovy kvóty. Do druhého skrutinia se pak převedly nevyužité hlasy a nepřidělené mandáty, přičemž ty se distribuovaly v jednom celostátním obvodě pomocí stejné kvóty, doplněné o metodu největších zbytků. Hlasy nepřekračující klauzuli proto propadaly. V českém prostředí, s ohledem na počet a významnost malých stran, přitom nebylo namístě očekávat, že by měl podíl propadlých hlasů přesahovat čtvrtinu odevzdaných, a umělá klauzule spolu sdanými pravidly přepočtu jsou proto hodnoceny stupněm 2 .

Před volbami v roce 2002 proběhla volební reforma, jejíž výstupy se od té doby v základních parametrech nezměnily. Navýšena byla klauzule pro koalice, a to na $10 \%, 15 \%$, resp. $20 \%$ ve shodné závislosti na počtu stran uvnitř koalice, což malým stranám výrazněji ztěžuje přístup do skrutinia. Počet volebních obvodů se zvýšil na 14 a k přidělování všech mandátů se od té doby využívá D’Hondtova metoda. Celostátně je tak poměr hlasů na mandát mezi stranami závislejší na rozložení jejich podpory. Teoretický vliv na podíl propadlých hlasů zůstal nezměněn. Nová aditivní klauzule pro koalice komplikuje jejich utváření, což v daných situacích může způsobovat menší úspěšnost malých stran, nicméně s ohledem na jejich počet a zisky se znovu nedá očekávat podíl propadlých hlasů nad $25 \%{ }^{20}$ Způsob rozdělení mandátů mezi kraje zůstal nezměněn, v důsledku čehož byly i nadále $\mathrm{v}$ zásadě omezeny možnosti mallaportionmentu. Jedinou změnu v následném období (volby 2010) představovalo navýšení počtu udělovaných preferenčních hlasů ze 2 na 4 a snížení procenta preferencí nutných k postupu na kandidátní listině ze $7 \%$ na $5 \%$ (Zákon č. 247/1995 Sb., ve znění ke dni 6. 11. 2006).

$\mathrm{Na}$ úrovni poslaneckých voleb v roce 1998 nemůžeme považovat za relevantní nařčení z účelového vymezení hranic obvodů kvưli zvýhodnění konkrétního subjektu, jelikož hranice obvodů kopírovaly územní kraje, kde nejméně lidnatý celek dosahoval zhruba poloviční hodnoty nejlidnatějšího kraje. Do dalších voleb byly schváleny obvody, které kopírovaly strukturu územního uspořádání na úrovni jednotek NUTS 3, přičemž se jednalo o samosprávné kraje. Toto umělé vymezení hranic však nedostatečně reflektovalo populaci nových krajů, když oproti předchozímu stavu dále zhruba dvojnásobně prohloubil rozdíl

20 Před volbami 2002 hrozil vysoký podíl propadlých hlasů v momentě, kdy by propadly hlasy Koalice KDU-ČSL, US-DEU, což se však nestalo. Navíc podíl takto propadlých hlasů by následně činil 14,27 \% hlasů, což by spolu s ostatními propadlými hlasy bylo na hraně $25 \%$. Strany se této překážce nicméně mohly vyhnout, přestože to mohlo mít dopad na fungování stranického systému. 
mezi nejlidnatějším a nejméně lidnatým krajem, což má dopad i na volební výstupy.

Hodnocení: 1998 - 1; 2002 - 2; 2006 - 2; 2010 - 2; 2013 - 2.

Praxe: Ani v jedněch sledovaných volbách nebyly zjištěny nedostatky $\mathrm{v}$ přepočítávání hlasů na mandáty. Tabulka 1 představuje hodnoty variačních koeficientů demonstrující rovnost hlasů ve volbách. Celkový variační koeficient ukazuje průměrnou odchylku podílu hlasů na mandát od průměrného počtu hlasů na mandát mezi stranami. Hodnota koeficientu męi kraji celkem značí, o kolik se $\mathrm{v}$ průměru odchylují podíly hlasů na mandát u všech stran $\mathrm{v}$ obvodech společně od jejich aritmetického průměru. V prrípadě využití volebních kvót se počítá $\mathrm{s}$ průměrným počtem hlasů na mandát $\mathrm{v}$ daném obvodu. ${ }^{21} \mathrm{Ve}$ volbách s více skrutinii je pak počítáno I. skrutinium stejně jako rovnost hlasů mezi kraji a II. skrutinium jako celkový výsledek, avšak pouze pro 15 mandátů.

Tabulka 1: Variační koeficienty podílů hlasů na jeden mandát pro jednotlivé volby

\begin{tabular}{|r|r|r|r|r|}
\hline \multirow{2}{*}{ Volby } & \multicolumn{3}{|c|}{ Variační koeficient } \\
\cline { 2 - 5 } & Celkový & I. skrutinium $^{1}$ & $\begin{array}{c}\text { II. } \\
\text { skrutinium }^{2}\end{array}$ & Mezi kraji celkem \\
\hline & & $7,46 \%$ & $6,46 \%$ & \\
1998 & $1,87 \%$ & $(185 \mathrm{M})$ & $(15 \mathrm{M})$ & $3,46 \%^{3}$ \\
\hline 2002 & $3,48 \%$ & & & $8,11 \%$ \\
\hline 2006 & $38,94 \%$ & & & $8,71 \%$ \\
\hline 2010 & $6,31 \%$ & & & $8,76 \%$ \\
\hline 2013 & $7,69 \%$ & & & $11,65 \%$ \\
\hline
\end{tabular}

1 - Hodnota koeficientu vypočitána jako (průměr podílů hlasů na jeden mandát [v prvním skrutiniu] jednotlivých stran) / (směrodatná odchylka těchto podílů)

2 - Hodnota koeficientu vypočítána jako (průměr podílů hlasů [využitých ve druhém skrutiniu] na jeden mandát jednotlivých stran) / (směrodatná odchylka těchto podílů)

3 - Hodnota platná pouze pro I. skrutinium

Zdroj: Vlastní výpočty na základě dat z Volby.cz (2015).

Je zřejmé, že ve volbách v roce 1998 byly všechny hodnoty nízké. V celkovém výsledku strany postoupivší do skrutinia potřebovaly téměř shodný počet hlasů na mandát (rozdíl oproti průměru je 1,87 \%). V těchto volbách však bylo využito více skrutinií, přičemž posoudíme-li skrutinia jednotlivě, byly i v nich

21 To znamená, že může teoreticky existovat strana, která nemá násobek takovéto (krajské) kvóty a přesto získala mandát, na který z tohoto pohledu nemusí mít nárok. 
dodrženy nízké odchylky od průměru. Byla tedy zajištěna rovnost hlasů nutných k zisku mandátu stran ve skrutiniu. Po volebních úpravách se od voleb 2002 zvýšila celková nerovnost hlasů mezi kraji. Odchylka od průměru zde činila asi 8 $11 \%$ počtu hlasů na jeden mandát. V celkovém výsledku, daném mj. citlivostí na velikost volebních obvodů, se především v roce 2006 promítl do hodnoty indexu zisk Strany zelených, která na jeden mandát potřebovala asi 2,4 krát více hlasů než v tomto smyslu nejúspěšnější ČSSD. Podíly hlasů na mandát ve zbylých volbách v tomto smyslu nepřekročily hranici pro snížení hodnocení (viz níže, zejm. pozn. 26). Nízká celková hodnota indexu ve volbách 2002 je pak dána především neobvykle vysokým ziskem nejmenšího subjektu. Problémem však zůstává, že uzavírací klauzule vyřazuje strany, které by na dané mandáty měly mít rovněž nárok. Přitom snížení klauzule byt' o $1 \%$ by v roce 2010 znamenalo postup dalších dvou stran do skrutinia. Klauzule způsobuje v komparativní rovině (srovnej Tavits a Annus 2006: 88-89) relativně průměrné podíly propadlých platných hlasů, a to 1998 - 11,32\%; $2002-12,53 \% ; 2006-5,97 \% ; 2010-18,83$ $\% ; 2013$ - 12,58 \% (Volby.cz 2015). To je však ospravedlňováno nutností zajištění akceschopnosti voleného tělesa. Celkové hodnocení neutrálnosti převodu hlasů na mandáty je stanoveno jako zaokrouhlený průměr hodnocení velikosti variačních koeficientů pro celkové volby a naprič kraji, podíl propadlých hlasì a hranice obvodü. ${ }^{22}$ Poslední jmenovaná kategorie ve volbách 1998 nabývá hodnoty 1, jelikož nelze říci, že by hranice volebních obvodů samy o sobě způsobovaly z(ne)výhodňování některých subjektů. Jejich úprava se na výsledcích voleb 2002 okamžitě neprojevila, jelikož rozdíly mezi nejvíce a nejméně zvýhodněnou stranou byly srovnatelné. Ve volbách 2006 se nicméně silně prohloubil rozdíl mezi těmito stranami, kdy prvá dosáhla nadreprezentace obdobné předchozím volbám, zatímco druhá (strana s nevhodně rozloženou podporou) nezískala ani polovinu mandátů, které jí bývaly měly poměrně prripadnout (hodnocení 4). To je zčásti dáno i úpravou hranic volebních obvodů, kdy Strana zelených v některých menších obvodech (především Liberecký, Královehradecký, Jihočeský) jen těsně neproměnila své hlasy na mandáty, což vedlo k její podreprezentaci. Od voleb 2010 k tomu již nedochází, avšak nadreprezentace velkých stran oproti ostatním je

22 Racionalita rozpětí jednotlivých kategorií hodnot je zde stanovena hodnotou rostoucí za každých započatých 12,5\% u procentuálních hodnot jednotlivých kategorií, a to proto, aby byly odchylky od ideálu přesahující $50 \%$ hodnoceny stupněm 5 , a to jak pro propadlé hlasy, tak pro variační koeficienty. Obecně vzato není zcela jasné, kde by se měla pohybovat hranice variačního koeficientu pro odmítnutí hlasování z důvodu nepřijatelného zvýhodnění některých hlasů z hlediska jejich dopadu na výsledek. Text srovnává váhu hlasů vedoucích ke zvolení daných kandidátů, jelikož je žádoucí, aby všechny hlasy měly stejný vliv na výsledek. Ovšem odborná literatura zabývající se vymezením volebních obvodů z hlediska jejich hranic a velikosti se opírá spíše o samotnou populaci $\mathrm{v}$ daných obvodech. V komparativním kontextu se odchylky od takovéhoto rovného vymezení obvodů pohybují od 0 (USA) do $30 \%$ (Singapur). Pro senátní volby v České republice se pak toleruje odchylka do 15 \% (\59 odst. 2 zákona č. 247/1995 Sb., ve znění pozdějších př̀edpisů). 
mnohem zřetelnější (viz Šedo 2007: 124-125 a vlastní dopočty na základě dat z Volby.cz 2015). Narychlo upravené (nejen) hranice volebních obvodů z roku 2002, vyznačující se značně rozdílnou velikostí a z toho plynoucích různých mechanických účinků (Charvát 2013: 139), se tedy projevily až od voleb 2010, nicméně již nikoli na úkor podreprezentace malých stran (hodnocení 2).

Hodnoceni: 1998 - 1; 2002 - 1; 2006 - 2; 2010 - 2; 2013 - 2.

Celkové hodnocení: 1998 - 2; 2002 - 3; 2006 - 4; 2010 - 4; 2013 - 4.

\section{h. Efektivní rozhodování sporů}

Pravidla: Ve volbách 1998 byly volební podvody postižitelné trestním zákonem, který upravoval pouze některé typy zjevných podvodů jako např́klad násilí a nucení př̀i volbě, padělání dokladů nebo špatné sčítání hlasů ( $\$ 177$ zákona č. 65/1994 Sb., ve znění ke dni 7. 4. 1994). To zůstalo fakticky nezměněno až do roku 2011, kdy k těmto podvodům přibyla možnost potrestat nakupování hlasů.

Jedním z problémů při dodržování volebních pravidel byla slabá vynutitelnost některých nař́żení $z$ důvodu absence postihů. Volby mohly být napadeny kvůli odmítnutí kandidátní listiny a škrtnutí kandidáta, nebo na základě stížnosti proti vydání osvědčení proti zvolení poslancem (\86 a \88 zákona č. 247/1995 Sb., ve znění ke dni 21. 6. 1998). Bylo také možné se domáhat nápravy chyb ve stálém seznamu voličů ( $\$ 200$ písm. j zákona č. 62/1996 Sb., ve znění ke dni 20. 3. 1996). Jednalo se pritom pouze o nápravné instituty, které nijak neodrazovaly od nedodržování zákona (s výjimkou aktivit uvedených v trestním zákoně). Př́padné spory v těchto věcech spadaly pod Nejvyšší soud (『 89 zákona č. 247/1995 Sb., ve znění ke dni 21. 6. 1998). Hodnocení těchto pravidel má hodnotu 3, jelikož možná náprava byla spjata prakticky výhradně s administrací voleb a jejich organizačně-technickou stránkou. Principy, jimiž by se volby měly řídit, zde byly po celé sledované období definovány velmi vágně, a bylo lze předpokládat zdrženlivost soudců při rozhodování o opakování voleb z důvodu porušení čestnosti nebo poctivosti kampaně.

Před volbami 2002 došlo $\mathrm{k}$ úpravě občanského soudního řádu a také volebního zákona. Nápravné instituty jsou rozšířeny o možnost přezkumu přihlášky k registraci a provedení registrace kandidátní listiny (\86 zákona č. 247/1995 Sb., ve znění ke dni 16. 6. 2002). Dále bylo možné využít návrhu na neplatnost volby kandidáta ( $\int 87$ tamtéž), který nahradil institut přezkumu vydání osvědčení o zvolení poslancem. Tento instrument byl do jisté míry nelogický vzhledem $k$ proporční povaze sněmovních voleb, kde jednotlivec nemůže zpochybnit celkový výsledek, ale pouze volbu kandidátů v jednom kraji (Molek 
2014: 520). ${ }^{23} \mathrm{~V}$ těchto volbách rovněž vyvstala otázka absence termínů pro rozhodování Nejvyššího soudu (NS) ve věcech registrace stran (viz dále). Decentralizace soudnictví v některých věcech, kdy krajské soudy měly pravomoc rozhodovat nezávisle bez možnosti využití opravných prostředků ( $\ 88$ odst. 1 zákona č. 247/1995 Sb., ve znění ke dni 1. 8. 2000), mohla být rovněž zdrojem problémů (viz dále). Volební zákon byl doplněn postihy za zveřejňování předvolebních průzkumů, týkající se jak fyzických osob, tak právnické osob provozujících rozhlasové nebo televizní vysílání (Zákon č. 247/1995 Sb., ve znění ke dni 1. 8. 2000). Pozvolnou úpravu pravidel v otázce zajištění efektivního rozhodování prrípadných sporů, konkrétně mírné rozšíření ochranných prvků či doplnění postihů za zveřejňování průzkumů, tak můžeme hodnotit pozitivně. $\mathrm{Na}$ druhou stranu s sebou změny prínášely i problémy, především kvůli decentralizaci rozhodovacího procesu a znejistění nařízení o napadení volby kandidáta. Hodnocení proto zůstává neměnné.

Volby 2006 zaznamenaly kosmetické změny pravidel spojené s novým soudním řádem správním (Zákon č. 150/2002 Sb., ve znění pozdějších předpisů), který nicméně zajišstuje obdobné možnosti nápravy jako doposud, a to ve věcech seznamů voličů ( $(88)$, registrace - ve věcech odmítnutí kandidátní listiny nebo přihlášky $\mathrm{k}$ její registraci, škrtnutí kandidáta na listině, registrování kandidátní listiny nebo přhlášky $\mathrm{k}$ registraci $(\$ 89)$ a neplatnosti volby kandidáta $(\mathbb{9} 90)$. Tato pravidla platí po zbytek sledovaného období. Problémy předchozích voleb se nijak nemění.

Ve volbách 2010 došlo pouze $\mathrm{k}$ upřesnění možnosti napadení voleb. NSS uvádí, že ,zatímco občan může předmětný návrh podat jen ve vztahu ke kandidátům, zvoleným ve svém volebním kraji tam, kde mohl vykonat svoje aktivní právo (...) je politická strana aktivně legitimována k podání tohoto návrhu vůči všem kandidátům, zvoleným v krajích, kde také kandidovala, což může $\mathrm{v}$ konečném důsledku znamenat zpochybnění i všech zvolených kandidátů v celé republice" (Usnesení NSS, č.j. Vol 5/2006). Tím je však zavedena další nerovnost nejen mezi strany a voliče, ale i mezi strany navzájem, jelikož platnost voleb mohou napadnout jen ty, které kandidují ve všech obvodech. Přestože tedy dochází k pozvolenému zlepšování podmínek, stále nejsou nijak vyřešeny problémy s vynutitelností nařízení a absencí principů upravujících průběh voleb. Principy čestnosti a poctivosti, využitelné spíše v př́edvolební kampani, jsou v tomto smyslu nedostatečné. Ve volbách 2013 je pak pouze doplněn trestní zákoník o možnost stíhání kupčení s hlasy (〔 351 zákona 40/2009 Sb., ve znění ke dni 1. 12. 2011).

Hodnoceni: 1998 - 3; 2002 - 3; 2006 - 3; 2010 - 3; 2013 - 3.

23 Přitom ve volbách do Senátu zákon umožňuje podat návrh nejen na neplatnost volby kandidáta, ale také na neplatnost hlasování a neplatnost voleb ( 887 odst. 2 zákona č. 247/1995 Sb., ve znění ke dni 1. 8. 2000). 
Praxe: Ve volbách 1998 si úředníci stěžovali na nevynutitelnost zákona, a to především na neschopnost vymáhat zákaz vylepování předvolebních materiálů v okolí volebních místností. Stížnosti na volby měly okrajový význam, bez dopadu na volební výsledek. Byl také umožněn dohled pozorovatelské mise při rozhodování Státní volební komise (OSCE 1998). Na celkovém hodnocení se tak slabá úprava pravidel spíše neprojevuje.

V roce 2002 vyvstaly v praxi dva zásadní problémy. Národní straně je de facto znemožněna účast ve volbách, jelikož NS kvưli vytíženosti nebyl schopen včas vyř́idit její stížnost na odmítnutí registrace Ministerstvem vnitra (OSCE 2002: 10). Koncem zárí 2002 pak NS rozhodl, že odmítnutí nebylo ministerstvem dostatečně odůvodněné (Rozsudek jménem republiky, sp. zn. 11 Zp 31/2001). Z hlediska podpory se sice jednalo o marginální stranu, nebyla jí však umožněna účast ve volbách.

Neefektivnost posuzování sporů je charakteristická pro př́pad rozdílného posouzení nezaplacení volebního poplatku strany AZS. Čtyři Krajské soudy totiž souhlasily s neregistrací kandidátní listiny této strany, zatímco další tři nařídily stranu registrovat, čímž došlo ke zvýhodnění strany v některých obvodech. Tomáš Lebeda k tomu poznamenal: „...narušuje to vůbec nějakou rovnou soutěž ve volbách a je otázka, zda skutečně ty výsledky voleb potom nebudou zpochybnitelné“ (Česká televize 2002). Ukazuje se, že problematická zákonná úprava v praxi volební výsledky nijak nezpochybnila (OSCE 2002: 9). ${ }^{24}$

Po volbách 2006 řešil NSS možnosti zpochybnění volby kandidáta v poslaneckých volbách, kdy nebylo možné zpochybnit volby jako celek. Ve své argumentaci však soud vyjasnil, kdo může volby jako celek zpochybnit (viz výše). Stížnosti byly vyřizovány rychle, avšak bez dopadu na pachatele, přestože někdy bylo prokázáno protizákonné jednání. Nikdy to ale nezpochybnilo volební výsledek. Přišel trest za únik „Kubiceho zprávy“. Vzhledem k jejímu mediálnímu pokrytí a možnému dopadu na volební výsledek byl však velmi mírný a navíc přišel až téměr dva roky po volbách. ${ }^{25}$ Především kvůli předvolebním událostem významně rostl počet stížností $\mathrm{k}$ NSS (z 18 na 70). Celkové hodnocení těchto voleb má hodnotu 2 , jelikož soudce ponechal prostor pro napadení voleb jako celku, přestože návrhy podané takto jednotlivými voliči byly zamítnuty.

V roce 2010 znovu zůstala některá pochybení bez následků pro pachatele, volebního výsledku se to však nijak nedotklo. Klesl také počet podaných stížností k NSS. Pětina z nich byla nicméně podána opožděně, pročež by stálo za promyšlení mírné prodloužení lhůty na podávání návrhů. Před volbami rozpustil

\footnotetext{
24 Přesto existovala teoretická možnost vlivu chybné registrace AZS v Jihočeském kraji na rozdělení mandátů, kterou však Ústavní soud odmítl jako spekulativní, přičemž, v kontextu vyjádření ČSÚ, se jevila jako nepravděpodobná (Usnesení Ústavního soudu č.j. II. ÚS 601/02).

${ }^{25}$ Peněžitý trest ve výši 25.000 Kč pro Pavla Severu (KDU-ČSL) a 9.000 Kč pro Ivana Langera (ODS).
} 
NSS Dělnickou stranu (DS). Členové DS však následně kandidovali za Dělnickou stranu sociální spravedlnosti. Stejně jako v předchozích volbách nedocházelo $\mathrm{k}$ excesům $\mathrm{v}$ podobě rozhodování krajských soudů.

Praktické fungování rozhodování sporů se ve volbách 2013 nijak zvláště nelišilo od těch předchozích. I přes rozpor se zákonem nebyla pochybení obvykle potrestána, výsledek voleb to však nijak neovlivnilo.

Hodnoceni: 1998 - 2; 2002 - 3; 2006 - 2; 2010 - 2; 2013 - 2.

Celkové hodnocení: 1998 - 5; 2002 - 6; 2006 - 5; 2010 - 5 2013 - 5.

\section{Shrnutí}

Nyní můžeme s ohledem na ovlivňování pravidel a samotnou praxi jejich naplňování identifikovat jednotlivé trendy jak celkově, tak i jednotlivě. Mưžeme vidět, že celkový index ${ }^{26}$ kvality pravidel se mezi roky 1998 a 2002 mírně snížil, což značí zvýšení integrity, nicméně od té doby stagnuje (Graf 1). Ke zhoršení $\mathrm{v}$ tomto smyslu dochází pouze $\mathrm{v}$ rámci neutrálnosti převodu hlasů na mandáty před volbami 2002. Nejhůře jsou na tom oblasti rovného informování a efektivního rozhodování sporů, které stagnují na hodnotě 3. Neznamená to však, že by zde nedocházelo ke změnám. Ty prrišly v rámci rovnosti informování především mezi volbami 1998 a 2002, kdy sledujeme drobné nápravy při omezení informování, což však bylo zastíněno zhoršením podmínek v oblasti financování stran - což se odrazilo ve větší nerovnosti mezi stranami při vedení kampaní. V rámci efektivního rozhodování sporů se do hodnocení promítá především skutečnost, že zajišt'ována byla pouze administrativní stránka voleb a řešeny pouze zjevné podvody, namísto stanovení jasných principů vymahatelných během celého volebního cyklu. Nicméně i zde v čase dochází k vyjasňování případných problémů spjatých s výkladem zákona. Mezi těmito volbami byly vyřešeny problémy týkající se volebního práva a dále se zlepšily i možnosti volit a právo být (z)volen. Problém v rámci svobodného vyjádření preferencí pak spočíá v teoreticky ne zcela zajištěné tajnosti volby. Přenosné sčítání výsledků je pak jedinou bezproblémovou oblastí v celém sledovaném období.

${ }^{26}$ Indexy jsou vypočteny jako průměry hodnot jednotlivých kategorií v daných volbách. 
Graf 1: Vývoj kvality pravidel upravujících volební soutěž do PS PČR v letech 1998-2013

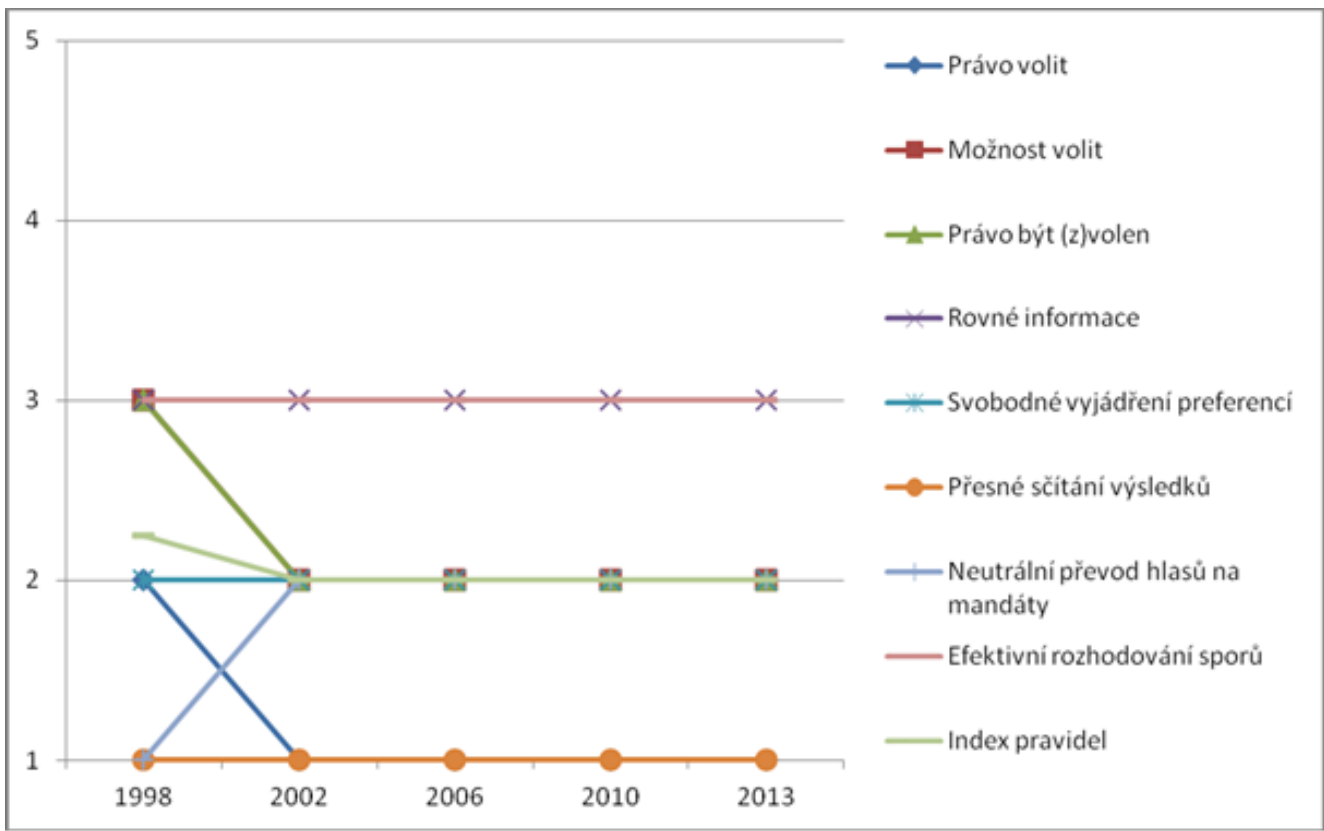

Zdroj: Autor, na základě výše formulovaných hodnocení.

Trend ovlivňování kvality voleb v praxi, v kontextu daných pravidel, znázorňuje graf 2 . Až do voleb 2006 sledujeme zlepšování kvality voleb. U voleb 2010 dochází k mírnému zhoršení hodnocení, na čemž se podepsalo předvolební násilí omezeného rozsahu vưči ČSSD, což zhoršilo hodnocení práva být (z)volen, přičemž ostatní ukazatele nabývaly mezi lety 2006-2013 konstantních hodnot. Přesnost sčítání výsledků a svobodné vyjádření preferencí se v praxi jeví jako bezproblémové. Další oblastí s konstantní, avšak problematickou hodnotou jsou rovné informace, přestože zde dochází k jistým pohybům. Změny jsou však protichůdné nebo malého významu, a proto se na hodnocení neprojevují. Ke zlepšení dochází $\mathrm{v}$ př́padě práva a možnosti volit, kdy v rámci prvního aspektu jsou do elektorátu zahrnuti dř́ve vyloučení voliči, zatímco $v$ rámci druhého je v omezeném rozsahu využívána možnost volby ze zahraničí. Negativní změny pravidel pro převod hlasů na mandáty se projevují až od voleb 2006, kdy byly nejmarkantnější a jen těsně se vyhnuly hodnocení 3 . V následných volbách se změny projevují výrazně méně až na hranici hodnocení 1 . V rámci efektivního rozhodování sporů se pak projevuje především slabá vymahatelnost pravidel, což v roce 2002 prohloubily problémy s nekonzistentností rozhodování soudů. 
Graf 2: Vývoj kvality praktického fungování volební soutěže do PS PČR v letech 1998-2013

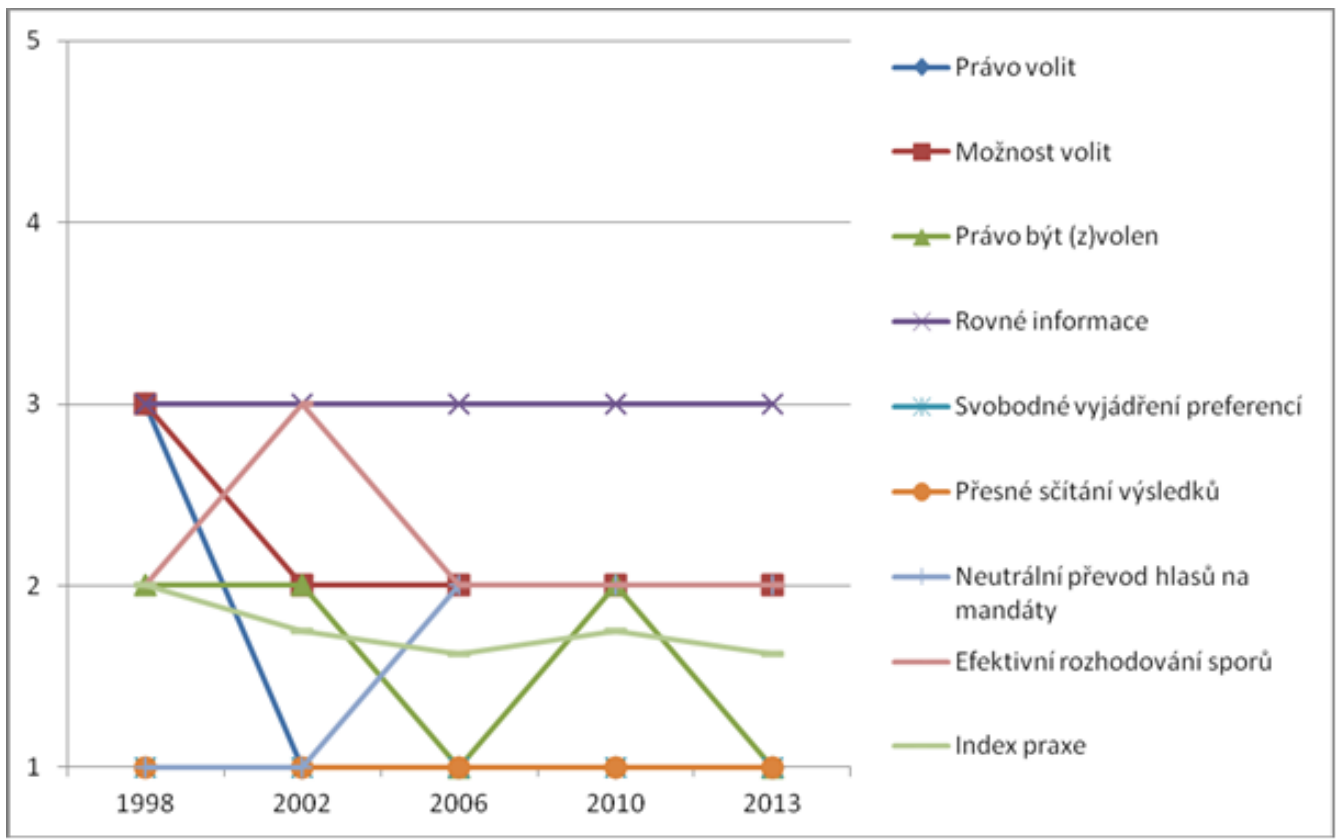

Zdroj: Autor, na základě výše formulovaných hodnocení.

Celková kvalita jednotlivých indikátorů a samotných voleb je znázorněna v grafu 3. Hodnoty na ose y představuji součet hodnot z pravidel a praxe. Pohybujeme se proto v rozmezí 2-10, přičemž 2 představuje nejvyšší možné hodnocení. Je zjevné, že celková kvalita voleb kopíruje trend fungování voleb v praxi. Pohybuje se přitom, mimo voleb 1998, do hodnoty 4, což v průměru značí hodnocení stále bez vlivu na volební výsledek. Jako nejproblematičtější oblastí se dlouhodobě jeví zajištení rovnosti informací a efektivní rozhodování sporů. Jsou zde však i jiné části cyklu, jejichž fungování není bez problémů. Tou první jsou samotná pravidla převodu hlasů na mandáty, jejichž nedotažená úprava z roku 2002 může v praxi přinášet různé obtíže. Normativně řečeno by bylo vhodné pravidla sladit v souladu s principem zajištění rovnosti hlasů, na základě rovnoměrné úpravy hranic obvodů, aby ve volbách pokud možno propadalo co nejméně hlasů. Výkyvy v hodnocení práva být (z)volen od roku 2002 mủžeme přičíst dobovým situacím v problematických volbách, jako byl problém s odvoláním se proti soudnímu rozhodnutí ve věci kandidatury nebo radikalizace společnosti s př́ichodem voleb. Do té doby však samotné nastavení procesu kandidatury ztěžoval samotný zákon. Bezproblémovou oblastí je be výjimky sčítání výsledků a jen o stupeň hůře dopadá svoboda vyjádření preferencí, jelikož $\mathrm{v}$ teoretické rovině zde existuje možnost nátlaku na voliče nebo označení jeho lístku před samotnou volbou. Výrazného zlepšení mezi volbami 1998 a 2002 pak 
doznaly právo a možnost volit, přičemž první jmenované je od té doby bezproblémové.

Graf 3: Vývoj celkové kvality volební soutěže do PS PČR v letech 1998-2013

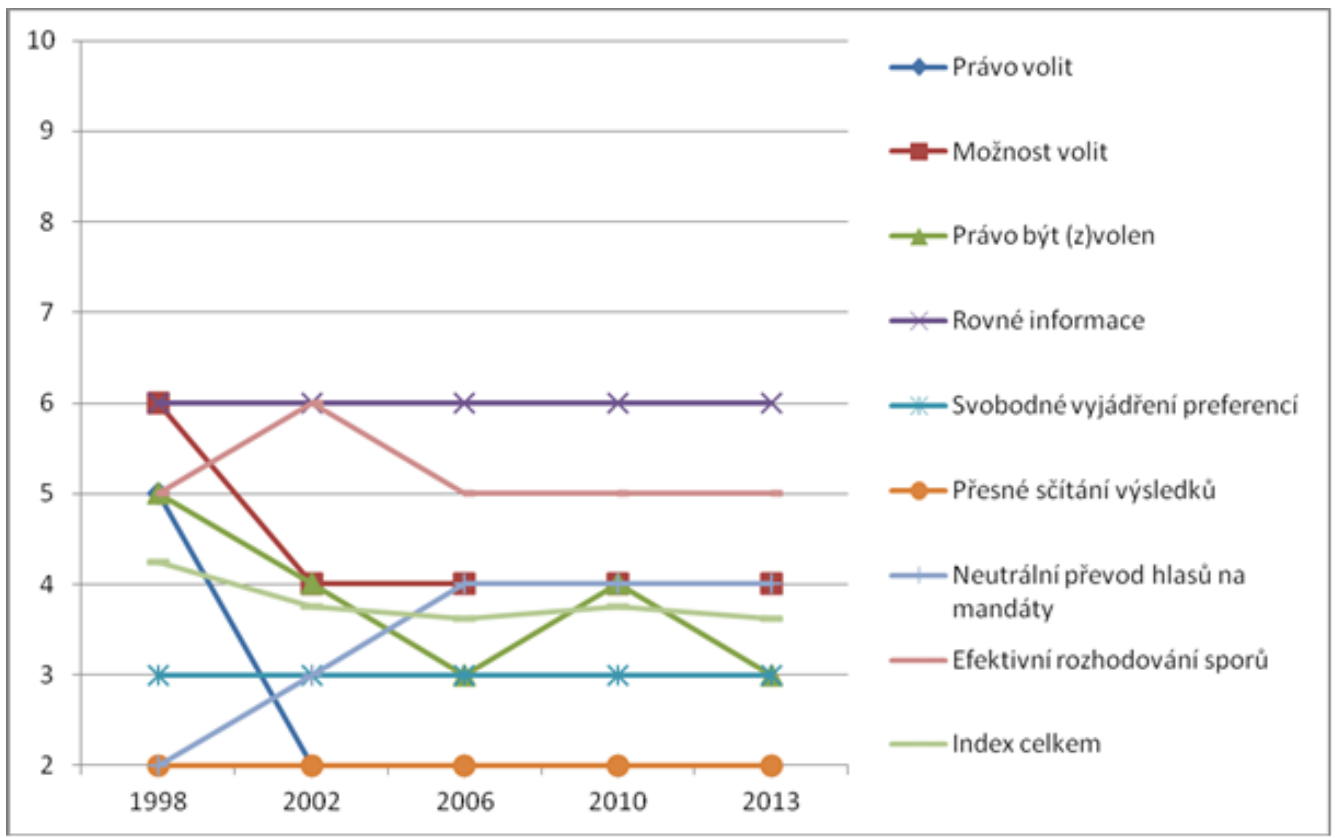

Zdroj: Autor, na základě výše formulovaných hodnocení.

\section{Závěr}

Tato studie měla za cíl zjistit, jaké jsou problémy českých parlamentních voleb $\mathrm{v}$ čase a zda můžeme sledovat nějaké trendy v jejich kvalitě. Normativní pojetí textu zvyšuje požadavky na bezproblémové volby, což se odráží na udělených hodnoceních. Rozsáhlá datová základna pak zvyšuje validitu daných zjištění. Výsledné celkové hodnocení však nijak významně nevybočuje ze zjištění jiných studií; identifikované problematické oblasti navíc odpovídají nešvarům v zavedených demokracích. Hlavní problém spočívá v medializaci a rovnosti informací spojených především s obdobím předvolební kampaně. Dalším zádrhelem může být struktura soudnictví pro volební účely, kde soudy mohou teoreticky rozhodovat $\mathrm{v}$ jednotlivých krajích $\mathrm{v}$ totožné věci různě, což bylo dlouhou dobu prohlubováno jednak úpravou stížností ve volebním zákoně, ale též jednoinstančností soudnictví. Existuje také problém slabé vymahatelnosti zákonných nařízení, jelikož v praxi nedocházelo $\mathrm{k}$ potrestání manipulátorů pouze proto, že nebyl prokázán dopad na volební výsledek a podobně. Z ostatních potenciálně problémových oblastí můžeme zmínit možnost volit nebo samotné nastavení volebního mechanismu. 
V obecné rovině můžeme pozorovat lepší reálný průběh voleb než jejich zákonné vymezení. To značí, že političtí aktéři dosud plně nezneužívají problémů, které vyplývají z nastavení pravidel. Celkové hodnocení je proto na velmi uspokojivých hodnotách. Kvalita voleb má v čase tendenci růst, avšak není to zaručeno (viz volby 2010). Některá hodnocení jsou přitom snížena spíše $\mathrm{v}$ důsledku negativního potenciálu některých problémů než v důsledku toho, že by se již v dostatečné míré projevovaly, což však do budoucna vyloučit nelze. Proto je záhodno sledovat další vývoj v daných oblastech a, prakticky vzato, př́padně učinit kroky potřebné $\mathrm{k}$ odstranění možných zdrojů těchto problémů.

Kritika takto normativně ukotveného textu se nabízí především prizmatem jiného prístupu ke studiu volební integrity a bude zřejmě směřovat na prŕísnost samotného hodnocení na první pohled bezproblémových voleb. V souladu s Dahlovým požadavkem zajištění dostatečné „míry, v jaké je př́itomna každá instituce v reálném smyslu“ (1995: 202) nicméně sledujeme ono naplnění jednotlivých požadavků kvalitních voleb, které se podobají právě Dahlovým institucím polyarchie. Je zjevné, že i v ČR existují velmi problematické oblasti ovlivňující výslednou kvalitu voleb, nicméně jejich počet je omezený a na celkovém hodnocení se projevuje minimálně. Můžeme proto mluvit o poměrně vysokém stupni volební demokracie s prostorem k parciálním změnám.

\section{Literatura a prameny}

ABC ČR (2016): „Periodický tisk.“ ABC ČR - Kancelár ověrováni nákladu tisku, on-line (http://www.abccr.cz/overovana-data/periodicky-tisk-

1/?filterMonth=9\&filterYear=2013\&filterNamePublisher=\&filterType=\&filterNameTi tle $=\&$ filterGenre=), [ověřeno k 22.3.2016].

ACE Electoral Knowledge Network (2016): „Comparative Data.“ Ace Electoral Knowledge Network, on-line (http://aceproject.org/epic-en), [ověreno k 16. 3. 2016].

Antoš, Marek (2008): Principy voleb v České republice. Praha: Linde.

Bazalová, Angelika (2013): „Názor: Kvapilová jen připomněla, že ČT špinavé prádlo schovávat nemá.“ iDnes.cz, 6. 9. 2013, on-line (http://zpravy.idnes.cz/nazor-kvapilovajen-pripomnela-ze-ct-spinave-pradlo-schovavat-nema-1 fn-

/domaci.aspx?c=A130906_125811_domaci_jpl), [ověřeno k 16.11.2015].

Bielasiak, Jack (2002): "The institutionalization of Electoral and Party Systems in Postcommunist States. “ Comparative Politics 34(2): 189-210.

Birch, Sarah (2011): Electoral Malpractice. Oxford: Oxford University Press.

Blažek, Ivan, Jan Rovenský, Lukáš Bek a Pavel Ohorzl (2010): „Žhář podpálil předvolební stánek ČSSD.“ Novinky.č, 6. 5. 2010, on-line (http://www.novinky.cz/domaci/199525-zhar-podpalil-predvolebni-stanek-cssd.html), [ověřeno k 11. 11. 2015].

Britské listy (2013): „Lidé, kteří mají voličský průkaz, mohou hlasovat několikrát?، B Britské listy, 25. 1. 2013, on-line (http://www.blisty.cz/art/67167.html), [ověřeno k 18. 11. 2015]. 
Černý, Ondřej a Jan Veselý (2002): „Manipulaci s volbami potvrdí test DNA.“ iDnes.č, 24. 6. 2006, on-line (http://zpravy.idnes.cz/manipulaci-s-volbami-potvrdi-test-dnad8m-/domaci.aspx?c=A020613_222328_zpr_volby_nad), [ověřeno k 12.11. 2015].

Česká televize (2002): „Př́íspěvky na volební náklady.“ ČT 2, 21, 20. 5. 2002.

ČTK (2006): „Soud v Mělníku nepotrestal ženu za manipulaci s volebními lístky.“ Beqkorupce, 27. 7. 2006, on-line (http://www.bezkorupce.cz/blog/2006/07/27/soud-vmelniku-nepotrestal-zenu-za-manipulaci-s-volebnimi-listky/), [ověřeno k 12. 11. 2015].

Dahl, Robert A. (1995): Demokracie a jeji kritici. (1. vyd.) Praha: Victoria Publishing.

Davis-Roberts, Avery a David J. Carroll (2010): „Using International Law to Assess Elections.“ Democratization 17(3), 416-441.

Diamond, Larry (2002): „Thinking About Hybrid Regimes.“ Journal of Democracy 13(1): 21 35. DOI: 10.1353 /jod.2002.0025

Ekiert, Grzegorz, Jan Kubik a Milada Anna Vachudova (2007): „Democracy in the PostCommunist World: An Unending Quest?." East European Politics and Societies 21(7): 7-30.

Gandhi, Jennifer a Ellen Lust-Okar (2009): „Elections Under Authoritarianism.“ Annual Review of Political Science 12: 403-422.

Geddes, Barbara (1999): „What do we know about democratization after twenty years?.“ Annual Review of Political Science 2: 115-144. DOI: 10.1146/annurev.polisci.2.1.115

GRECO (2011): „Evaluation Report on the Czech Republic on Transparency of party funding (Theme II)." Group of States against corruption, 1. 4. 2011. On-line (http://www.coe.int/t/dghl/monitoring/greco/evaluations/round3/GrecoEval3(2010) 10_CzechRep_Two_EN.pdf), [ověřeno k 12.11. 2015].

Gregor, Miloš a Alena Macková (2014): „Předvolební kampaně 2013: Prohloubení trendů, nebo nástup nových?.“ In: Vlastimil Havlík (eds.), Volby do Poslanecké snèmovny 2013. Brno: Masarykova univerzita, Fakulta sociálních studií, Mezinárodní politologický ústav, 55-71.

Huntington, Samuel P. (1991): The third wave: Democratization in the late twentieth century. Norman: University of Oklahoma Press.

Charvát, Jakub (2013): Politika volebních reforem v ČR po roce 1989. Praha: Grada.

Jarabinský, Ivan (2015): „Appearances are deceptive: credibility of the Russian Election Commission." East European Politics 31(1): 88-103. DOI: $10.1080 / 21599165.2014 .990960$

Jiřička, Jan (2013): „Exšéfka Nových médií Kvapilová v ČT definitivně končí, dostala výpověd'“" iDnes.č, 11. 9. 2013, on-line (http://zpravy.idnes.cz/ct-vyhodila-kvapilovou0v3-/domaci.aspx?c=A130911_105532_domaci_ji), [ověřeno k 16. 11. 2015].

Kelley, Judith (2012): The Good, the Bad, and the Ugly: Rethinking Election Monitoring. Stockholm: International IDEA.

Lidovky.cz (2013a): „Nevědí, s kým mají tu čest, stěžoval si Babiš na LN. Pak se omluvil.“, Lidovky.cz, 28. 6. 2013, on-line (http://www.lidovky.cz/nevedi-s-kym-majitu-cest-stezoval-si-babis-na-ln-pak-se-omluvil-pbx-/zpravydomov.aspx?c=A130628_173145_ln_domov_rak), [ověřeno k 16.11.2015].

Lidovky.cz (2013b): „Drtinovou stáhlo vedení z Událostí po politickém nátlaku, tvrdí odbory.“ Lidovky.cz, 9. 8. 2013, on-line (http://byznys.lidovky.cz/stazeni-drtinove-zudalosti-vyhovuje-politickemu-natlaku-tvrdi-odbory-1a7-

/media.aspx?c=A130809_114455_ln-media_mct), [ověřeno k 16. 11. 2015]. 
Lust-Okar, Ellen (2006): „Elections under authoritarianism: Preliminary lessons from Jordan." Democratization 13(3): 456-471. DOI: 10.1080/13510340600579359

Macková, Alena a Lenka Hrbková (2014): „Média a volby.“ In: V. Havlík (eds.), Volby do Poslanecké snémovny 2013. Brno: Masarykova univerzita, Fakulta sociálních studií, Mezinárodní politologický ústav, 73-91.

Magaloni, Beatriz (2008): „Credible Power-Sharing and the Longevity of Authoritarian Rule." Comparative Political Studies 41(4/5): 715-741. DOI: 10.1177/0010414007313124

Magaloni, Beatriz. (2010): „The Game of Electoral Fraud and the Ousting of Authoritarian Rule." American Journal of Political Science 54(3): 751-765. DOI: 10.1111/j.1540-5907.2010.00458.x

Matušková, Anna (2006): „Volební kampaň 2006: nástup politického marketingu do České republiky. “ In: Dalibor Čaloud, Tomáš Foltýn, Vlastimil Havlík a Anna Matušková (eds.), Volby do Poslanecké snémovny v roce 2006. Brno: CDK, 62-88.

Matušková, Anna (2010): „Volební kampaně.“ In: Stanislav Balík (eds.), Volby do Poslanecké snémovny v roce 2010. Brno: CDK, 97-115.

Ministerstvo vnitra ČR (2014): Zpráva o extremismu na územi České republiky 2013. Praha: Ministerstvo vnitra $\check{C} R$. on-line (http://www.mvcr.cz/clanek/extremismus-vyrocnizpravy-o-extremismu-a-strategie-boje-proti-extremismu.aspx), [ověreno k 11. 11. 2015].

Ministerstvo vnitra ČR (s.d.): Možnost volit prí volbách do Poslanecké snèmovny Parlamentu České republiky vroce 2013 vnemocnici nebo vobdobném zarízení. on-line (http://www.mvcr.cz/clanek/moznost-volit-pri-volbach-do-poslanecke-snemovnyparlamentu-ceske-republiky-v-roce-2013-v-nemocnici-nebo-v-obdobnem-zarizeni.aspx), [ověřeno k 11. 11. 2015].

Mlejnek, Josef (2010): „Paroubek se porazil sám.“ Revue Politika (6). on-line (http://www.revuepolitika.cz/clanky/1313/paroubek-se-porazil-sam), [ověřeno k 24. 2. 2015].

Molek, Pavel (2014): Politická práva. Praha: Wolters Kluwer.

Nález Ústavního soudu ze dne 13. 10. 1999, sp. zn. Pl. ÚS 30/98, vyhlášený pod č. 243/1999.

Norris, Pippa (2014): Why electoral integrity matters. New York: Cambridge University Press.

Novinky.cz (2006): „US-DEU má jasno, do voleb půjde sama.“ Novinky.cz, 17. 2. 2006, on-line (http://www.novinky.cz/domaci/77857-us-deu-ma-jasno-do-voleb-pujdesama.html), [ověreno k 16. 11. 2015].

OSCE (1998): „Czech Republic Parliamentary Elections 19 and 20 June 1998: Final Report." OSCE, 20. 7. 1998, on-line (http://www.osce.org/odihr/elections/czechrepublic/16147?download=true), [ověřeno $\mathrm{k} 11.11 .2015$ ].

OSCE (2002): „Czech Republic Parliamentary Elections 14-15 June 2002: Final Report.“ OSCE, 16. 7. 2002, on-line (http://www.osce.org/odihr/elections/czechrepublic/16109?download=true), [ověřeno k 11. 11. 2015].

OSCE (2010): „Czech Republic Parliamentary Elections 28-29 May 2010: OSCE/ODIHR Needs Assessment Mission Report 22-25 March 2010.“ OSCE, 16. 4. 2010, on-line (http://www.osce.org/odihr/elections/67702?download=true), [ověřeno k 16. 11. 2015].

Outlý, Jan (s.d.): „Analýza financování politických stran v České republice.“ Sblị́̌eni politikou, on-line (http://www.sblizenipolitikou.cz/odborne-analyzy), [ověřeno k 11. 3. 2016]. 
Ovčáček, Jiř́ a Jan Rovenský (2013): „Zemanovci se obrátili na policii, prý se kopírují voličské průkazy.“ Novinky.cz, 25. 1. 2013, on-line (http://www.novinky.cz/domaci/291353-zemanovci-se-obratili-na-policii-pry-sekopiruji-volicske-prukazy.html), [ověřeno k 18. 11. 2015].

Petrová, Barbora (2006): „Volební kampaň v médíích.“ In Dalibor Čaloud, Tomáš Foltýn, Vlastimil Havlík a Anna Matušková (eds.), Volby do Poslanecké snémovny v roce 2006. Brno: CDK, 42-61.

Petrová, Barbora (2010): „Média a volební kampaň.“ In Stanislav Balík a kol., Volby do Poslanecké snèmovny v roce 2010. Brno: CDK, 117-133.

Předpis č. 231/2001 Sb., Zákon o provozování rozhlasového a televizního vysilání a o změně dalších zákonů, ve znění pozdějších předpisů.

Rada pro rozhlasové a televizní vysílání (2013): Analýza obchodníbo sdèlení „Vodñanské kure", on-line

(http://www.rrtv.cz/cz/files/monitoring/2013_analyza_obchodnich_sdeleni_vodnans ke_kure.pdf), [ověřeno k 16.11.2015].

Rada pro rozhlasové a televizní vysílání (2014): Stanovisko Rady pro rozblasové a televizni vysilani ze dne 19. $11.2014, \quad$ on-line (http://www.rrtv.cz/cz/static/metodiky/stanovisko_politicka_reklama.pdf), [ověřeno k 12. 11. 2015].

Radiožurnál (1998): „ČT a veřejnoprávnost.“ Radiožurnál, 27. 5. 1998.

Romové v České republice (2000): „Romové v České republice - cizinci ve vlastní zemi.“ Romové V Ceské republice, 26.2.2000, on-line (http://romove.radio.cz/cz/clanek/18823\#zakon), [ověřeno k 11. 11. 2015].

Rozsudek jménem republiky ze dne 17. 2. 2010, sp. zn. Pst 1/2009, on-line (http://www.nssoud.cz/docs/Delnicka_strana_original.pdf), [ověřeno k 16.11. 2015].

Rozsudek jménem republiky ze dne 27. 9. 2002, sp. zn. 11 Zp 31/2001, on-line (http://kraken.slv.cz/11Zp31/2001), [ověřeno k 16.11.2015].

Schedler, Andreas (2002a): „The Nested Game of Democratization by Elections.“ International Political Science Review 23(1): 103-122. DOI: 10.1177/0192512102023001006

Schedler, Andreas. (2002b): „The Menu of Manipulation.“ Journal of Democracy 13(2): 3650. DOI: 10.1353 /jod.2002.0031

Schedler, Andreas. (2006): Electoral Authoritarianism: The Dynamics of Unfree Competition. Boulder, CO: Lynne Riener.

Schumpeter, Joseph A. (2004): Kapitalismus, socialismus a demokracie. Brno: Centrum pro stadium demokracie a kultury.

Sedláček, Štěpán a Pavel Herot (2011): „Srovnání mediální agendy politických stran před volbami do Poslanecké sněmovny Parlamentu ČR v letech 2006 a 2010.“ Naše společnost 9(2): 3-14.

Šedo, Jakub (2007): Volební systémy postkomunistických zemí. Brno: Centrum pro studium demokracie a kultury.

Škraňková, Petra a Josef Kopecký (2006): „Evropští demokraté demonstrovali před vládou.“ iDnes.č, 12. 4. 2006, on-line (http://zpravy.idnes.cz/evropsti-demokratedemonstrovali-pred-vladou-f4w-/domaci.aspx?c=A060412_094115_domaci_skr), [ověřeno k 16. 11. 2015]. 
Šrajbrová, Markéta (2012): „Lidé protestovali neplatnými lístky, pomohla i fáma.“ Aktuálnè.cz, 15. 10. 2012, on-line (http://zpravy.aktualne.cz/domaci/lide-protestovalineplatnymi-listky-pomohla-i-fama/r i:article:760379/), [ověřeno k 11. 11. 2015].

Transparentní volby (2013): Strany a politická bnutí, on-line (http://www.transparentnivolby.cz/snemovna2013/), [ověřeno k 31. 3. 2016].

Tavits, Margit a Taavi Annus (2006): „Learning to make votes count: The role of democratic experience.“ Electoral Studies 25(1): 72-90. DOI: 10.1016/j.electstud.2005.02.003

Třeček, Čeněk, Barbora Lukšová a Václav Prak (2010): „Bohuslav Sobotka dostal na mítinku ČSSD pěstí, útočník měl 1,88 promile." iDnes.č, 5. 5. 2010, on-line (http://zpravy.idnes.cz/bohuslav-sobotka-dostal-na-mitinku-cssd-pesti-utocnik-mel-188-promile-1jc-/domaci.aspx?c=A100505_183648_brno-zpravy_cen), [ověřeno k 11. 11. 2015].

Třeček, Čeněk, Dan Prokop a Lucie Jelínková (2006): „Poslance ČSSD Váňu napadl neznámý útočník.“ iDnes.cz, 30. 5. 2006, on-line (http://zpravy.idnes.cz/poslance-cssdvanu-napadl-neznamy-utocnik-fim-/krimi.aspx?c=A060530_121913_krimi_cen), [ověřeno k 11. 11. 2015].

Týden.cz (2010): „Útok na Paroubkovu ženu? Policie nabídla ochranku.“ Týden.cz, 13. 5. 2010, on-line (http://www.tyden.cz/rubriky/domaci/volby-2010/utok-na-paroubkovuzenu-policie-nabidla-ochranku_168849.html), [ověřeno k 11.11. 2015].

U.S. Department of State (1999): „Czech Republic Country Report on Human Rights Practices for 1998." U.S. Department of State, 26. 2. 1999, on-line (http://www.state.gov/www/global/human_rights/1998_hrp_report/czechrep.html), [16. 11. 2015].

U.S. Department of State (2003): „Czech Republic: Country Reports on Human Rights Practices." U.S. Department of State, 31. 3. 2003, on-line (http://www.state.gov/j/drl/rls/hrrpt/2002/18361.htm), [ověřeno k 12. 11. 2015].

U.S. Department of State (2007): „Czech Republic.“ U.S. Department of State, 6. 3. 2007, on-line (http://www.state.gov/j/drl/rls/hrrpt/2006/78808.htm), [ověřeno k 16. 11. 2015].

U.S. Department of State (2011): „2010 Human Rights Reports: Czech Republic.“ U.S. Department of State, 8.4 4. 2011, $\quad$ on-line (http://www.state.gov/j/drl/rls/hrrpt/2010/eur/154420.htm), [ověřeno k 16.11. 2015].

U.S. Department of State (s.d.): „Czech Republic 2013 Human Rights Report.“ U.S. Department of State, on-line (http://www.state.gov/documents/organization/220481.pdf), [oveřeno k 16. 11. 2015].

Usnesení Nejvyššího správního soudu ze dne 26. 6. 2006, č.j. Vol 5/2006.

Usnesení Nejvyššího správního soudu ze dne 22. 6. 2010, č.j. Vol 13/2010.

Usnesení Nejvyššího správního soudu ze dne 29. 6. 2006, č.j. Vol 27/2006.

Usnesení Nejvyššího správního soudu ze dne 29. 6. 2006, č.j. Vol 15/2006.

Usnesení Nejvyššího správního soudu ze dne 19. 6. 2006, č.j. Vol 8/2006.

Usnesení Nejvyššího správního soudu ze dne 21. 11. 2013, č.j. Vol 143/2013-27.

Usnesení Ústavního soudu ze dne 7. 1. 2003, č.j. II. ÚS 601/02.

Ústavní zákon č. 1/1993 Sb., ve znění pozdějších předpisů.

Volby.cz (2015): Výsledky voleb a referend, on-line (www.volby.cz), [ověřeno k 18. 11. 2015]. 
Válková, Hana a Pavel Eichler (2010): „Lahev na mítinku ČSSD neletěla od diváků. Incident vyšetřuje policie.“ iDnes.cz, 5. 5. 2010, on-line (http://zpravy.idnes.cz/lahevna-mitinku-cssd-neletela-od-divaku-incident-vysetruje-policie-11a/krimi.aspx?c=A100505_141158_krimi_hv), [ověřeno k 11.11.2015].

Vyhláška č. 452/2013 Sb., kterou se mění vyhlášky provádějící volební zákony, ve znění účinném k 1. 1. 2014.

Werner, Lukáš a Michal Verner (2010b): „Rekordní účet za kampaň: až jeden a půl miliardy." Týden.cz, 2. 6. 2010, on-line (http://www.tyden.cz/rubriky/domaci/volby2010/rekordni-ucet-za-kampan-az-jeden-a-pul-miliardy_171131.html), [ověřeno k 16. 11. 2015].

Zákon č. 2/1993 Sb., o vyhlášení LISTINY ZÁKLADNÍCH PRÁV A SVOBOD jako součásti ústavního pořádku České republiky, ve znění pozděǰších předpisů.

Zákon č. 29/1984 Sb., o soustavě základních a středních škol (školský zákon), ve znění účinném k 27. 7. 1995.

Zákon č. 40/1993 Sb., o nabývání a pozbývání státního občanství České republiky, ve znění účinném k 21. 6. 1998.

Zákon č. 40/2009 Sb., trestní zákoník, ve znění účinném k 1. 12. 2011.

Zákon č. 62/1996 Sb., Občanský soudní řád (úplné znění, jak vyplývá z pozdějěích změn a doplněnî), ve znění účinném $\mathrm{k}$ 20.3. 1996.

Zákon č. 65/1994 Sb., Trestní zákon (úplné znění, jak vyplývá z pozdějších změn a doplněnî), $v$ citovaných zněních.

Zákon č. 84/1990 Sb., o právu shromažd’ovacím, ve znění pozdějších předpisů.

Zákon č. 103/1992 Sb., o Radě České republiky pro rozhlasové a televizní vysílání

Zákon č. 111/1998 Sb., o vysokých školách a o změně a doplnění dalších zákonů (zákon o vysokých školách), ve znění pozdějších předpisů.

Zákon č. 150/2002 Sb., soudní rád správní, ve znění pozdějších předpisů.

Zákon č. 172/1990 Sb., o vysokých školách, ve znění účinném k 1. 7. 1990.

Zákon č. 247/1995 Sb., o volbách do Parlamentu České republiky a o změně a doplnění některých dalších zákonů, $v$ citovaných zněních.

Zákon č. 424/1991 Sb., o sdružování v politických stranách a v politických hnutích, ve znění pozdějších předpisů.

Zákon č. 483/1991 Sb., o České televizi, ve znění pozdějších předpisů.

Zákon č. 561/2004 Sb., o předškolním, základním, středním, vyšším odborném a jiném vzdělávání (školský zákon), ve znění pozdějších předpisů.

Žantovský, Petr (2015): Mediálni manipulace a krize v Ceské televiz̨i v roce 2000. Praha: Institut Václava Klause. 


\title{
Quality of Elections to the Chamber of Deputies of the Parliament of the Czech Republic
}

\author{
SUMMARY
}

The democratization of elections in 1989 and 1990 in central and eastern Europe was the starting point of multiple pathways to truly democratic elections in this region. The dynamics of electoral reform have varied and the goals of such reform are certainly not considered to be unselfish. At least for this reason the quality of elections should not be taken for granted.

The aim of this work is to describe problematic aspects regarding the quality of elections to the Chamber of Deputies of the Parliament of the Czech Republic. These problems can play a role with respect to wider international evaluations and rankings, which are usually based on expert assessments. However, such assessments are often made retrospectively without deeper evaluation and the validity of these studies can be reduced. Therefore, it is important to focus more closely on the quality of elections in the Czech Republic. The research questions are then straightforward: "What are the problems relating to parliamentary elections?" and "Can we identify any trend in the quality of these elections?" Elections from 1998 to 2013 were chosen for this study, mainly because of a lack of comparable sources of information regarding earlier elections.

In general, the quality of Czech elections is ranked very highly in comparison with other countries. However, the quality is never perfect and by examining individual electoral phases we can not only identify particular forms of misconduct but also better understand where the potential for fraud and other forms of misconduct lies.

This article is based on the framework of electoral integrity, from which Sarah Birch's concept of electoral malpractice was derived. This framework is normatively based on a "policy accountability" model of democracy which was previously used by Birch (2011). It allows the whole electoral cycle and all necessary aspects of elections to be covered. Therefore, we examine the following aspects of elections: the right to vote, the opportunity to vote, the right to stand for election, equal information, the free expression of preferences, accurate counting, neutral vote-to-seat conversion, and the effective adjudication of disputes. These aspects are individually evaluated and the resulting scores are then individually commented upon. The ranking is made on a scale of 1 to 5 , where 1 stands for elections of the highest quality and 5 for those of the worst. Number 5 is not, however, used only for cases in which all aspects are seriously deficient; it is also used for all elections in which misconduct allows one actor to artificially gain dominance. The assessments are made on two levels in every part of the cycle, i.e. on the level of rules (the legal framework) and on the level of the game (real behaviour in elections, and the working of the framework). These assessments are then combined to make an overall assessment of each aspect. The overall quality of elections is then determined by calculating the mean value of all eight individual assessments. The analysis is based on various kinds of sources, mainly reports by international observers, laws, secondary analyses, and local news.

The main results are as follows: During the examined period the overall quality of elections grew at both levels - rules and games, with an exception of the 2010 elections. 
The quality of elections was also very high at both levels. Regarding electoral rules, equal information and the effective adjudication of disputes were identified as the most problematic aspects. During the studied period, equal information was mainly influenced by uneven access to state resources and by vague formulations of the law. The main problem with the effective adjudication of disputes lay in the fact that the structure of the electoral judiciary is decentralized with no possibility to appeal to a higher court. In one particular election, it occurred that different courts dealing with the same problem made different judgments.

As regards the practical conduct of elections, results of single indicators oscillate more significantly than is the case with rules. In general, however, results seem to be worse on the level of rules than on the level of the real election process. This indicates that individuals taking part in elections do not exploit all the existing deficiencies of the rules; as a result, elections seem to be of higher quality than the legal framework would suggest. Again, the equal information aspect received the worst score. Apart from that, in only two elections did the quality of certain (altogether three) indicators drop to the score of 3. These were the right and opportunity to vote in 1998 and effective dispute adjudication in 2002. The other parts of the electoral cycle reveal rather positive results with no or at best speculative impact on elections. In general, the overall trend in the quality of electoral game between 1998 and 2006 was positive (increasing). Although there was a rare drop in 2010 due to rising aggression towards one party before elections, it quickly returned back to the 2006 levels.

The overall conclusions are thus generally positive. The trends in the quality of elections as such follow the same pattern as the real-world process of elections. The accuracy of votes counting can be considered exceptionally high. Also, the most problematic aspects of elections overlap both in theory and practice, as the differences between rules and election outcomes are rather low. With the exception of equal information and the effective adjudication of disputes, problems associated with elections to the lower chamber of the Czech parliament seem to be rather minor and without a discernible effect on electoral results. In general, the assessment offered in the paper confers on the Czech parliamentary elections high ranking in international comparative perspective. However, there is certainly still room for improvement. 